\title{
YERBILIMLER I
}

Bulletin for Earth Sciences

Yerbilimleri, 2019, 40 (1), 1-34, DOI:10.17824/yerbilimleri.496519

Hacettepe Üniversitesi Yerbilimleri Uygulama ve Araştırma Merkezi Bülteni

Bulletin of the Earth Sciences Application and Research Centre of Hacettepe University

\section{Bir demir cevherinden manyetit ve bakır kazanımı amacıyla entegre bir akım şeması geliştirme stratejileri}

Strategies for developing an integrated flow-sheet for the recovery of magnetite and copper from an iron ore

\section{ERGIN GÜLCAN ${ }^{1,{ }^{* A}}$, ÖZCAN YILDIRIM GÜLSOY ${ }^{1 \mathrm{~B}}$, ILKAY BENGÜ CAN ${ }^{1 \mathrm{C}}$, MEHMET ÖZYURT $^{2 \mathrm{D}}$, ERGUN TUNCER ${ }^{2 E}$}

\footnotetext{
${ }^{1}$ Hacettepe Üniversitesi, Maden Mühendisliği Bölümü, 06800, Beytepe, Ankara, TÜRKIYE

${ }^{2}$ Bilfer Madencilik ve Turizm A.Ş., Ataç Sk.35/6 Yenişehir-Çankaya-Ankara, TÜRKIYE
}

Geliş (received): 13 Aralık (December) 2018 Kabul (accepted): 13 Nisan (April) 2019

\section{ÖZ}

Son yıllarda ağır sanayi ve demir-çelik endüstrisinin enerji maliyetlerini düşürmeye yönelik talepleri, manyetit ve demir cevherlerinin safsızlık alt sınırlarının düşmesine sebep olmuştur. Daha yüksek kalite hedefleri konvansiyonel akım şemalarının sınırlarını zorlamakta ve metal verimi bir problem haline gelmektedir. Bu çalışmada, Erzincan bölgesinde bulunan demir cevherindeki manyetit ve bakırın zenginleştirilebilirliğine yönelik çalışmalar yürütülmüştür. Deneysel çalışmalarda yüksek verimde ve kalitede manyetit cevherinin yanında satılabilir tenörde bakır eldesi hedeflenmiştir. Bu kapsamda detaylı mineralojik ve karakterizasyon çalışmalarını takiben manyetik ayırma ve flotasyon yöntemleri kullanılarak ilgili cevherin ekonomik olarak değerlendirilebilirliği incelenmiştir.

Deneysel çalışmalar kapsamında $-500 \mu \mathrm{m},-300 \mu \mathrm{m}$ ve $-106 \mu \mathrm{m}$ boylarında kademeli manyetik ayırma testleri, manyetik ayırma ile kalite artırımı testleri, -75 $\mu \mathrm{m}$ ve $-53 \mu \mathrm{m}$ boylarında manyetik ayırma atığı ve beslemeden bakır kazanımı testleri gerçekleştirilmiştir. Elde edilen ürünlerin demir içerikleri yeterince yüksek olmakla birlikte, sonuçlar yaş manyetik ayırmanın da tek başına yeterince temiz ürün üretmekte yeterli olmadığını göstermiş, sonrasında manyetik ürünün toplu sülfür flotasyonuna tabi tutulması ile impüritelerin daha da azaltılabileceği belirlenmiştir.

https://doi.org/10.17824/yerbilimleri.496519

Ergin GÜLCAN ergingulcan@hacettepe.edu.tr

\footnotetext{
${ }^{A}$ Hacettepe Üniversitesi, Maden Müh. Böl., 06800, Beytepe, Ankara, TÜRKIYE, ORCID 0000-0002-8861-8061, ergingulcan@hacettepe.edu.tr,

${ }^{B}$ Hacettepe Üniversitesi, Maden Müh. Böl., 06800, Beytepe, Ankara, TÜRKIYE, ORCID 0000-0002-7063-7432, ogulsoy@hacettepe.edu.tr,

${ }^{C}$ Hacettepe Üniversitesi, Maden Müh. Böl., 06800, Beytepe, Ankara, TÜRKIYE, ORCID 0000-0002-3335-9285, ilkay@hacettepe.edu.tr,

${ }^{D}$ Bilfer Madencilik ve Turizm A.Ş., Ataç Sk.35/6 Yenişehir-Çankaya-Ankara, TÜRKIYE, mehmetozyurt@bilfer.com.tr,

${ }^{E}$ Bilfer Madencilik ve Turizm A.Ş., Ataç Sk.35/6 Yenişehir-Çankaya-Ankara, TÜRKIYE, erguntuncer@bilfer.com.tr.
} 
Ayrıca manyetik ayırma sonrasında flotasyonla sülfür içeriği düşürülen nihai konsantreden bir çökelme tankı ile kaba şlam atılması durumunda silis, alümina ve magnezyum içerikleri daha düşük ürünler elde edilebileceği anlaşılmıştır.

Devamında, deneysel çalışmalar sonucunda elde edilen veriler kullanılarak simülasyon destekli tesis tasarımı çalışmaları gerçekleştirilmiştir. Elde edilen sonuçlara göre tasarlanan akım şeması ile \%87-88 demir verimli ve \%65.5-66.5 Fe tenörlü bir manyetit konsantresinin yanında, yaklaşık \%47 verimle \%18-19 Cu tenörlü bakır konsantresinin de elde edilmesi mümkün olmaktadır.

Anahtar sözcükler: Manyetit, bakır, manyetik ayırma, flotasyon.

\section{ABSTRACT}

Through recent years, demand to reduce energy costs in iron and steel industry have triggered the need to lessen the critical limits of impurities in magnetite and iron ores. Higher targets in final product quality are pushing the boundaries of conventional process schemes and recovery becomes a problem. In this study, studies on enrichment of magnetite and copper in an iron ore of Erzincan region have been carried out. Experimental studies have aimed to obtain salable grade copper concentrate efficiently along with the magnetite product. In this context, after detailed mineralogical characterization studies, the evaluation of the relevant ore was examined by using magnetic separation and flotation methods.

Experimental studies covered gradual magnetic separation tests at $-500 \mu \mathrm{m},-300 \mu \mathrm{m}$ and -106 $\mu \mathrm{m}$ sizes, quality enhancement tests with magnetic separation, and copper and magnetite recovery from tail and feed samples at particle sizes of $-75 \mu \mathrm{m}$ and -53 $\mu m$. While the iron content of the obtained products was sufficiently high, the results showed that the wet magnetic separation alone was not enough to produce perfectly clean products. It had also been determined that the impurities could also be further reduced by subjecting the magnetic product to bulk sulfur flotation. Additionally, the low sulfur-final concentrate obtained after flotation and magnetic separation processes was subjected to desliming process, thus lowering silica, alumina and magnesium contents in final product.

Following simulation-assisted process, flowsheet design studies were carried out using the data obtained from experimental studies. According to the results, it was possible to obtain a magnetite concentrate with 65.5-66.5\% Fe-grade (87.5-86\% iron 
recovery) along with a salable copper concentrate having $18-19 \%$ Cu-grade (47\% copper recovery).

Keywords: Magnetite, copper, magnetic separation, flotation.

\section{GíRiş}

Günümüz ağır ve metalurji sanayileri, üretim hedeflerini karşılamak için yüksek kaliteli hammaddelere intiyaç duymaktadır. Metalurjik hammaddeler, temelde metal içeriği endüstriyel standartlar ölçüsünde yüksek olan ve zenginleştirmeye ekonomik olarak uygun olan doğal minerallerden oluşan konsantrelerdir. Buradan hareketle maden kaynaklarının en verimli şekilde kazanımı amacıyla hem endüstri standartlarında kaliteli metalik konsantreler elde etmek, hem de mevcut cevherin barındırdığı tüm metalleri uygun yöntemlerle kazanmak zorunluluğu doğmaktadır. Bu kapsamda değerli yan ürünlerin de verimli bir şekilde eldesi önem kazanmaktadır.

Ağır ve metalurji sanayi endüstrilerinden özellikle demir üretimine dayalı çelik endüstrisi, maliyeti düşürmek için gittikçe artan yüksek kaliteli hammaddeler talep etmektedir (Holmes ve Lu, 2015). Nihai konsantrede alkali, alüminyum, fosfor ve sülfür safsızlıklarının oldukça kritik düzeylere çekildiği talepleri karşılamak için mineralojik olarak zorlayıcı demir cevherlerinin iyi planlanmış zenginleştirilme işlemlerine tabi tutulması gerekmektedir (Lovel vd., 2015). Bununla birlikte cevherin bünyesinde değerli sülfür minerallerinin de bulunması ve serbestleşme sorunlarının da mevcut olması durumunda zenginleştirme işleminde ultra-ince boylara inilmesi zorunluluğu doğmaktadır. İnceliğin yeterli olması durumunda geleneksel gravite yöntemleri, manyetik ayırma, flotasyon ve seçimli flokülasyon yöntemleri ayrı ayrı veya kademeli olarak demir zenginleştirilmesinde uygulanabilmektedir (Rousseau, 1987; Napier-Munn, 2005; Gupta ve Yan, 2016a; Gupta ve Yan, 2016b; Gupta ve Yan, 2016c).

Manyetik ayırma, manyetik alınganlığı yüksek demir cevherlerinin manyetik özellikte olmayan alkali ve silikatlı safsızlıklardan ayrımasının en etkin yoludur (Clout ve Manuel, 2015; Ezhov ve Shvaljov, 2015; Xiong vd., 2015; Quast, 2018). Demir cevherinin türü, yapı-doku özellikleri, mineralojisi, sınıflandırılması ve bunların fiziksel ve kimyasal özellikleriyle ilişkileri zenginleştirme stratejisinin belirlenmesinde büyük önem taşımaktadır (Clout ve Manuel, 2015). Buradan hareketle cevhere özgü, 
yüksek veya düşük alan şiddetlerinde, yaş veya kuru uygulanacak olan kademeli manyetik ayırma testleri tasarlanmaktadır.

En yaygın demir cevheri türleri manyetit ve hematittir (Haldar ve Tisljar, 2014). Hematit cevheri doğrudan metalurjik işlemlere tabi tutulmadan önce genellikle $-30+10$ mm (fındık) ve -10 mm (toz) olarak sınıflandırılır (Mare vd., 2015). Bu boylarda ürün eldesi amacıyla kırma ve eleme işlemleri uygulanır. Manyetit cevheri ise bünyesindeki silis matrislerinin ve diğer safsızlıkların uzaklaştırıması amacıyla mikron boylarında zenginleştirilir (Jankovic, 2015). Bununla birlikte manyetik alınganlığı daha düşük hematit ve limonit cevherlerinin mineralojik ve proses kaynaklı gerekçelerle mikron boyutunda yüksek alan şiddetli manyetik ayrıma ile zenginleştirildiği örnekler de mevcuttur (Song vd., 2002). Manyetitten farklı olarak limonit ve hematitin manyetik ayırma işlemi, sodyum oleat ile floküle edilen malzeme kullanılarak gerçekleştirilir.

30 mikron seviyelerine kadar inmenin normal bir prosedür olduğu manyetik ayırma ile manyetit kazanımı, safsızlıkların değerli metal ve elementler içerdiği cevherleşmelerde dikkatli bir mineralojik çalışma gerektirmektedir. Nadir toprak elementlerinin kazanımında manyetik ayırma ve flotasyonun birlikte kullanıldığı zenginleştirme yöntemlerine benzer şekilde, manyetitin sülfürlü bileşenlerinin değerli metaller içerdiği durumlarda fiziksel ve yüzey kimyasına dayalı karma akım şemalarının tasarlanması önem kazanmaktadır (Xionga vd., 2018). Bu amaçla manyetik ayırmanın flotasyon ile entegre edildiği kontrollü akım şemaları kullanılarak gerek atıktan değerli metallerin kazanılması, gerekse manyetik ayırma konsantresinin temizlenmesi mümkün olmaktadır (Xiong vd., 2015; Wanga vd., 2018).

$\mathrm{Bu}$ çalışma kapsamında bünyesinde sülfür, alüminyum, fosfor ve silis gibi matris düzeyinde safsızlıklar ile yer yer pirit oluşumları ve kalkopirit minerali barındıran bir manyetit cevherinin zenginleştirilebilirliği incelenmiştir. Bu kapsamda detaylı mineralojik karakterizasyon çalışmalarını takiben, cevher yapısına ve tane boyuna bağlı olarak en uygun manyetik ayırma ve flotasyon koşulları araştırılmıştır. Elde edilen sonuçlar doğrultusunda, ilgili manyetit cevherinin ekonomik olarak zenginleştirilebileceği bir tesis tasarlanmıştır. 


\section{NUMUNE KARAKTERIZASYON VE HAZIRLAMA ÇALIŞMALARI}

Bu makale kapsamında BILLFER Madencilik ve Turizm A.Ş.'ye ait (Bizmişen) bakır içeren kompleks yapıdaki manyetit cevherinin zenginleştirilebilirliği incelenmiştir. Deneysel çalışmalarda kullanılmak üzere sondaj çalışmalarından elde edilmiş olan karotlardan kompozit ve temsili bir numune hazırlanmıştır. Yapılan kimyasal analizler sonucunda cevherin ortalama demir ve bakır içeriğinin sırasıyla \%46-48 Fe ve \%0.10-0.13 Cu olduğu görülmektedir. Bununla birlikte sülfür, alüminyum, fosfor ve silis içeriklerinin yaklaşık olarak sırasıyla \%1-2 S, \%2-3.5 $\mathrm{Al}_{2} \mathrm{O}_{3}, \% 0.02 \mathrm{P}, \% 12.5-15$ $\mathrm{SiO}_{2}$ arasında olduğu belirlenmiştir.

Karakterizasyon çalışmaları kapsamında karot numunelerinden el örnekleri seçilmiştir. El örnekleri farklı yapı ve dokuların tanımlanması amacıyla mikroskop altında incelenmek üzere kullanılmıştır (Şekil 1). Şekil 1'de görüldüğü üzere cevher çoğunlukla manyetitten oluşan, mika, feldspatlar, kil ve sülfür minerallerini içeren bir yapıya sahiptir. Cevher, yapısal olarak yüzeyi temiz ve yer yer ince boyda alümina ve alkali ( $\mathrm{Al}, \mathrm{Ca}, \mathrm{Mg}, \mathrm{K}$ ve $\mathrm{Na}$ ) geçişlerine sahip manyetit tanelerinden oluşmaktadır. Manyetit genel olarak iri tane boylarında bulunmaktadır. Ayrıca pirit oluşumları ile birlikte bakır minerali olarak kalkopirite rastlanmıştır. Manyetit yanında bozunma ürünü olan martitleşme de gözlenmektedir. Yan kayaç minerallerinden olan kuvars bazen masif bazen de cevher mineralleri arasında matriks yapıda bulunmaktadır. El örneklerindeki cevher minerallerini mikroskop altında daha iyi görebilmek için bu örneklerin Struers Mineralojik Kesit Parlatma cihazında parlak kesitleri hazırlanmıştır. Parlak kesitler üstten aydınlatmalı metalografik mikroskopla incelenmiştir. Elde edilen görüntülerde cevher minerali olarak çoğunlukla manyetit, pirit ve kalkopirite rastlanmıştır. 


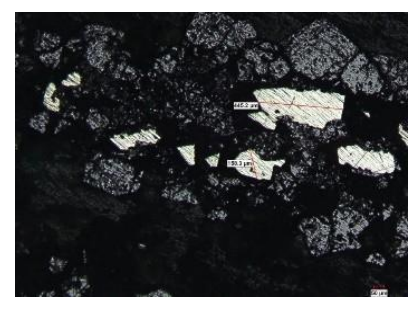

1 No'lu kayaç

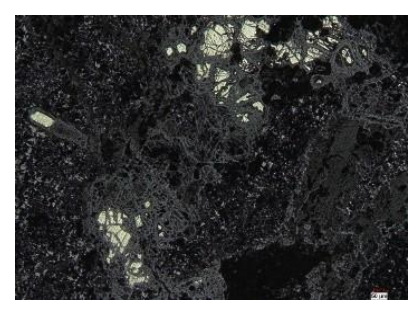

4 No'lu kayaç

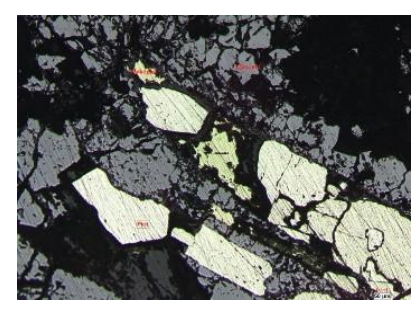

2 No'lu kayaç

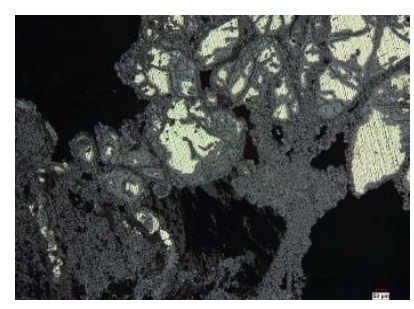

5 No'lu kayaç

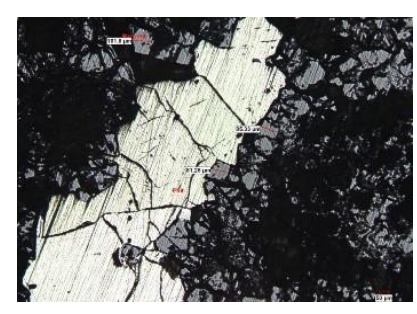

3 No'lu kayaç

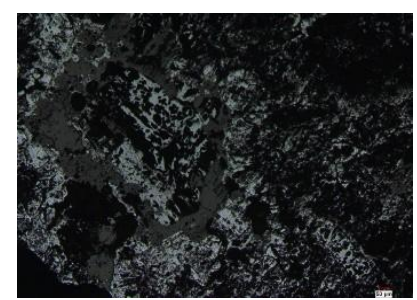

6 No'lu kayaç

Şekil 1. Karot numunelerinden alınan altı farklı parlak kesit numunesinin genel görünümü.

Figure 1. Overview of six different surface-polished section samples taken from core samples.

Şekil 1'de verilen parlak kesitler detaylı incelendiğinde;

- 1 No'lu kayacın parlak kesit görüntüsünde yan kayaç matriksi içine dağılmış olan pirit ve manyetit mineralleri görülmektedir. Bu görüntüde minerallerin tane büyüklüğü 150-500 $\mu \mathrm{m}$ aralığında değişmektedir.

- 2 No'lu kayaç örneğinde manyetit ve pirit damarları arasında kalkopirit minerali görülmektedir. Özellikle kalkopiritin $106 \mu$ m'den daha iri tane büyüklüğünde olduğu görülmektedir. Diğer minerallerle olan yapı-doku ilişkisi incelendiğinde bu minerale ilişkin serbestleşme problemiyle karşılaşıımayacağı öngörülebilir. Fakat bakırdaki oksidasyonun nihai bakır verimi üzerinde etkili olabilmesi mümkündür.

- 3 No'lu kayaç örneğinin parlak kesit görüntüsünde yine ana cevher minerali olarak manyetit ve piritin olduğu görülmektedir. Pirit çatlaklı yapıdadır. Manyetit ise yaklaşık $106 \mu$ m'nin altındaki tane boylarında, pirit damarı etrafında matriks minerali içinde dağılmıştır. Matriks mineralinin (silikatlar) manyetit taneleri arasındaki ince sokulumları bu yapının serbestleşme sorunu çıkartacağının önemli bir göstergesidir. 
- 4 No'lu kayaç örneğinin parlak kesit görüntüsünde diğer kayaç örneklerine göre daha farklı bir yapı-doku örneği mevcuttur. Pirit minerali manyetit mineralinin içindeki boşluklarda büyüme göstermektedir. Manyetit minerali diğer kayaç örneklerinden farklı olarak birbirinden bağımsız taneler halinde olmayıp birbirine bağlı bir ağ yapısı sergilemektedir. Bu yapı da ince boyda serbestleşme gerekliliğini işaret etmektedir.

- 5 No'lu kayaç örneği de 4 No'lu kayaç örneğine benzer yapıdadır ve manyetit içinde pirit büyümeleri görülmektedir. Kayacın bazı kesimleri cevher minerali olarak sadece manyetitten oluşmaktadır. Pirit çok az miktarda ve ince boyda dağılmış durumdadır. Özellikle nihai üründeki kükürt içeriğinin düşürülmesine yönelik olarak manyetit içindeki pirit kapanımlarının serbestleştirilmesi gerekmektedir. Bu da ince boylara öğütme ile olabilir. Özellikle bazı pirit

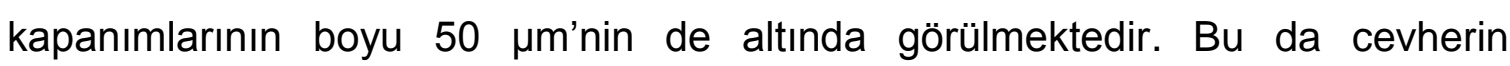
zenginleştirme testleri sonunda elde edilecek nihai ürününe bakılarak öğütme boyunun daha ince boylara indirilmesini gerektirebilir.

- 6 No'lu kayaç örneğinde manyetit minerali yan kayaçla birlikte görülmektedir. Cevherde manyetit oldukça iri tane boyuna sahip olmakla birlikte, bazı numunelerde ince pirit kapanımları ve doku içine girmiş silikatlı mineraller görülmektedir. İri $(500 \mu \mathrm{m})$ boylarda zenginleştirme yapılabilir. Fakat cevherin içerdiği ince boylardaki pirit nedeniyle nihai ürünün kükürt içeriği hedef değerlerin üzerinde kalabilir. Bu nedenle ince boylara öğütme yapılarak manyetit konsantresinin bu boylarda üretilmesi gerekebilir. Bazı boylarda özellikle silikatı yan kayaçla dokunaklı bölgelerde alterasyon ve manyetit dışındaki demirli mineral yapısı mevcuttur. Buralarda killeşmeye benzer yapılar da görülmektedir. $\mathrm{Bu}$ durum nihai manyetik üründe alümina içeriğini artırabilir. Bozunma ürünleri dikkat çekicidir. Martitleşme düşük alan şiddetli manyetik ayırma ile yapıdaki tüm demirin kazanılmasına izin vermeyecek şekilde dağılım göstermektedir. Bozunma ürünü olması nedeniyle killeşme de bu yapıda sorun oluşturabilir.

Karakterizasyon çalışmalarının devamında, cevherin öğütülmesine yönelik olarak laboratuvarda Bond İş İndeksi belirleme testi gerçekleştirilmiştir. Standart Bond değirmeni kullanılarak yapılan testte manyetit numunesine ait iş indeksi değeri, 9.70 kWh/t olarak hesaplanmıştır. Serbestleşme verileri cevherin iri boyda zenginleştirilmesinin mümkün olmadığını ortaya koymaktadır. Buradan hareketle üç 
farklı süre için cevherden alınan temsili numuneler laboratuvar değirmeninde öğütülmüş ve elde edilen tane boyu dağılımları Şekil 2'de verilmiştir. Çalışmanın devamında 25 ve 20 dk öğütme süreleri kullanılarak $d_{90}$ boylarının sırasıyla $-75 \mu \mathrm{m}$ ve $-53 \mu \mathrm{m}$ olduğu ürünler elde edilebileceği görülmektedir. Bunlara ek olarak yine mineralojik serbestleşme verilerden yola çıkılarak $d_{100}$ boylarının $-500 \mu \mathrm{m},-300 \mu \mathrm{m}$ ve -106 $\mu \mathrm{m}$ olduğu numuneler hazırlanmıştır. Her ne kadar mineraloji ince boyda serbestleşme göstermiş olsa da özellikle iri boylardan başlanarak zenginleştirme yapılıp yapılamayacağının da deneysel çalışmalar kapsamında ayrıca incelenmesi planlanmıştır. Çizelge 1'de $-500 \mu \mathrm{m},-300 \mu \mathrm{m}$ ve $-106 \mu \mathrm{m}$ öğütme boyları için satmagan (Saturation Magnetization Analyzer) cihazı ile belirlenmiş olan

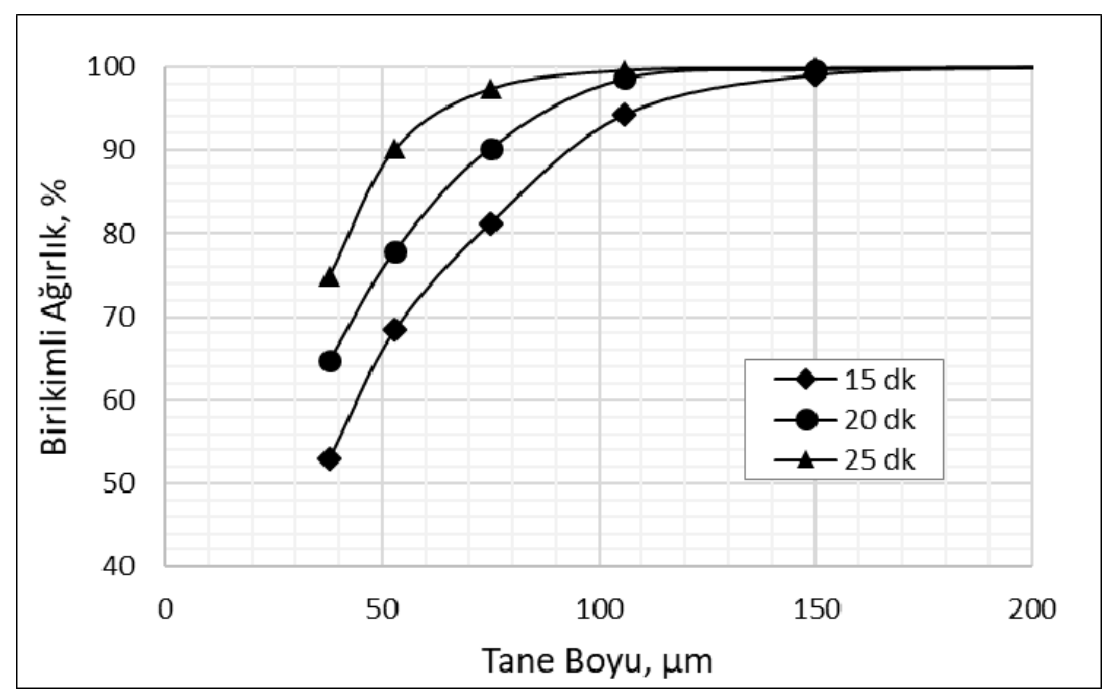

Şekil 2. 15, 20 ve 25 dakika öğütme sonucunda elde edilen tane boyu dağılımları.

Figure 2. Particle size distributions obtained after 15, 20 and 25 min grinding operations.

boyları için satmagan (Saturation Magnetization Analyzer) cihazı ile belirlenmiş olan manyetit $\left(\mathrm{Fe}_{3} \mathrm{O}_{4}\right)$ içeriği ve \%Fe içerikleri verilmektedir. Çizelge 1'de görüldüğü gibi demirli bileşenlerin tamamı manyetit değildir. Manyetit kaynaklı Fe miktarı kimyasal analizle ölçülmüş olan Fe miktarından küçüktür. Bu da cevherdeki Fe'nin tamamının manyetit kaynaklı olmadığını göstermektedir. Bu durum deneysel tasarım aşamasında göz önünde tutulması gereken diğer önemli bir noktadır. 


\begin{tabular}{|c|c|c|c|}
\hline Farklı inceliklere öğütülmüş besleme & Manyetit \% & $\% \mathrm{Fe}$ & $\% \mathrm{Cu}$ \\
\hline$-500 \mu \mathrm{m}$ & 47.8 & 46.33 & 0.11 \\
\hline$-300 \mu \mathrm{m}$ & 48.8 & 46.93 & 0.12 \\
\hline
\end{tabular}

Çizelge 1. Cevherin manyetit içeriği ve \% Fe içerikleri.

Table 1. \% Magnetite and Fe contents of the ore.

\section{DENEYSEL YÖNTEM}

Deneysel çalışmalar kapsamında cevherin genel yapısına bağı olarak, manyetit cevherinden ince boyda manyetit ve flotasyon ile bakır ürünü alınması, aynı zamanda da alkali ve alümina gibi safsızlıkların da uzaklaştııımasına yönelik test çalışmaları planlanmıştır. Zenginleştirme deneylerinde kullanılacak deneysel yöntem, mineralojik veriler ve cevherin serbestleşme davranımı göz önünde bulundurularak tasarlanmıştır. Bu kapsamda farklı sondaj karotlarından alınan ocak numunesi -10 mm'ye kırımış ve temsili numune gruplarına ayrımıştır. Öncelikle bir grup temsili -10 $\mathrm{mm}$ numune iri boyda atık (gang) minerallerinin uzaklaştırılabilirliğini incelemek amacıyla, düşük alan şiddetli kuru manyetik ayırma testlerine (cobbing) tabi tutulmuştur. Devamında, belirlenen tane boylarına öğütülen numunelerle nihai ürünlerdeki kayıplar göz önünde bulundurularak düşük alan şiddetli yaş manyetik ayırma testleri, yüksek alan şiddetli yaş manyetik ayırma testleri ve nihai kalite artışına yönelik yaş manyetik ayırma ve flotasyon testleri gerçekleştirilmiştir. Elde edilen sonuçlar doğrultusunda ilgili cevherin en yüksek verimle zenginleştirilebileceği bir akım şeması tasarlanmıştır.

\section{Manyetik Ayırma Testleri}

Düşük alan şiddetli kuru manyetik ayırma testlerinde orijinal sondaj karotları $-10 \mathrm{~mm}$ tane boyuna indirilerek iki kademeli olarak temizlenmiştir. Bu kapsamda Şekil 3'de verilen akım şeması doğrultusunda düşük alan şiddetli kuru manyetik ayırıcı ile 900 Gauss ve takiben 500 Gauss alan şiddetlerinde testler gerçekleştirilerek manyetit içeriği yüksek bir ürün alınması hedeflenmiştir. 


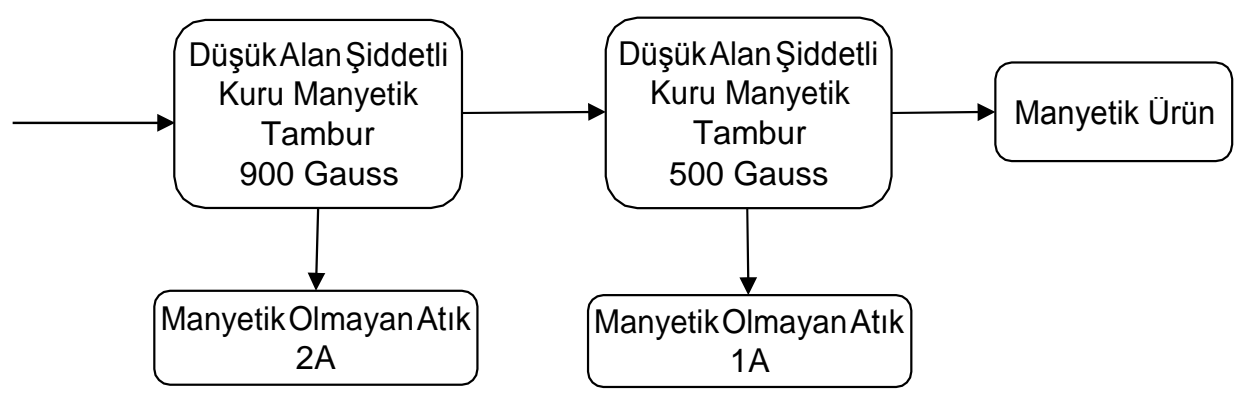

Şekil 3. -10 mm'ye kırılmış numune ile yapılan düşük alan şiddetli kuru manyetik ayırma (cobbing) testleri şematik görünümü.

Figure 3. Schematic view of low intensive dry magnetic separation (cobbing) tests performed with $-10 \mathrm{~mm}$ crushed sample.

Düşük alan şiddetli yaş manyetik ayırma testleri kapsamında, mineralojik veriye uygun olarak $-500 \mu \mathrm{m},-300 \mu \mathrm{m}$ ve $-106 \mu \mathrm{m}$ tane boylarında üç farklı numune grubu hazırlanmıştır. Düşük alan şiddetli yaş manyetik ayırma testlerinin gerçekleştirilmesi amacıyla tambur tipi bir yaş manyetik ayıııcı kullanıımışıı. Şekil 4'de üç farklı incelikte öğütülmüş malzemeye uygulanmış olan yaş manyetik ayırma testlerinin şematik olarak görünümü verilmektedir. Yaş manyetik ayırma testlerinde besleme numunesi öncelikle 900 Gauss alan şiddetinde zenginleştirilerek bir atık atılmış ve alınan manyetik ürün 600 Gauss alan şiddetinde tekrar temizlenmiştir. Yine 600 Gauss'da alınan manyetik ürünün sırasıyla 400 Gauss alan şiddetinde bir defa ve 250 Gauss alan şiddetinde iki defa olmak üzere toplam beş kademe temizlenerek nihai ürün elde edilmiştir. Her kademede atıklar ve manyetik ürünlerden numuneler alınarak analiz edilmiştir. Manyetik ayırma nihai atığı ile gerçekleştirilmesi planlanan $\mathrm{Cu}$ flotasyonu testlerinde kullanılmak üzere 10 kg'ın üzerinde nihai atık elde edilene kadar testlere devam edilmiştir.

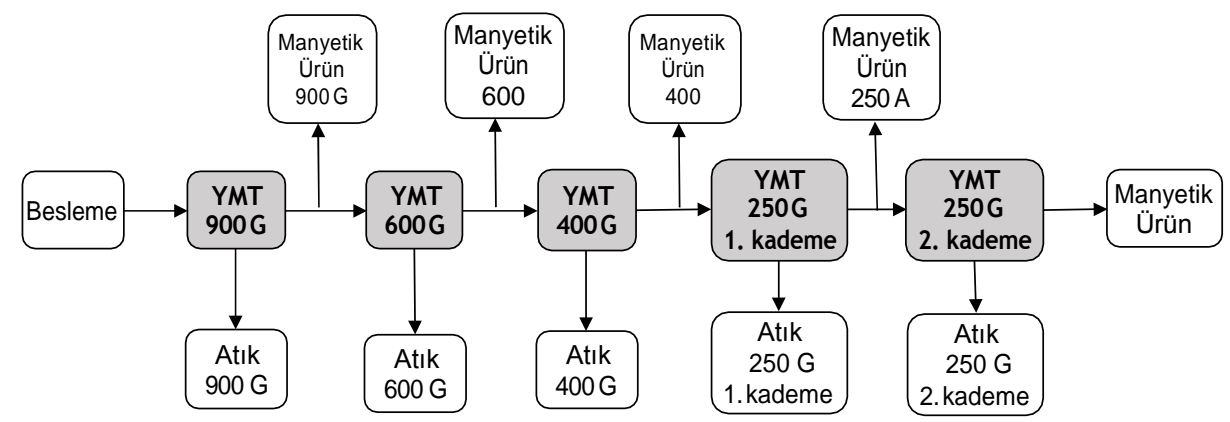

Şekil 4. Yaş manyetik ayırma testleri akım şeması (YMT: Yaş manyetik ayırma testi).

Figure 4. Flowsheet of the wet magnetic separation tests (YMT: Wet magnetic separation tests). 
Düşük alan şiddetli yaş manyetik ayırma işleminde demir (\% Fe) kaybı kaçınılmaz olmaktadır. Bu kayıplardan demir kazanımını incelemek amacıyla düşük alan şiddetli yaş manyetik ayırma sonrasında manyetik olmayan kısma giden atık; yüksek alan şiddetli, yaş, matriks tipi ayırıcıyla manyetik ayırma işlemine tabi tutulmuştur. Uygulanan yüksek alan şiddetli yaş manyetik ayırma testlerinin şeması Şekil 5'de verilmektedir. Bu işlemde öncelikle alan şiddeti $1.1 \mathrm{~T}$ değerine ayarlanarak mümkün olduğunca demirli mineraller yakalanmaya çalışılmış. Daha sonra bu aşamada alınan manyetik ürün 0.8 T alan şiddetinde temizlemeye tabi tutulmuştur.

\section{Flotasyon ile Bakır Kazanımı ve Kalite Artışına Yönelik Testler}

Flotasyon çalışmalarında manyetik ayırma sonrasında elde edilen konsantreden sülfürlü minerallerin uzaklaştırılması ve atıktan bakır konsantresi eldesi amaçlanmıştır. Flotasyon testlerinde Denver tipi flotasyon makinesi kullanılmıştır.

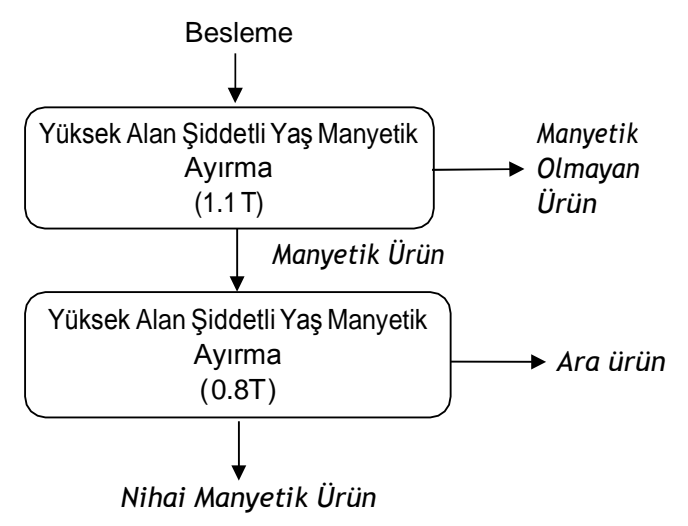

Şekil 5. Atığa uygulanan yüksek alan şiddetli yaş manyetik ayırma işlemi test şeması. Figure 5. High-gradient wet magnetic separation test procedure applied to waste.

Kaba flotasyon aşamasında 4.5 It hacimli hücre kullanılarak flotasyon işlemi \%35 ağırıkça katı palp yoğunluğunda gerçekleştirilmiştir. Temizleme flotasyonu aşamalarında 1 It hacimli hücreler kullanılmıştır. Uygulanması planlanan testlerin basit şeması Şekil 6'da verilmektedir. 


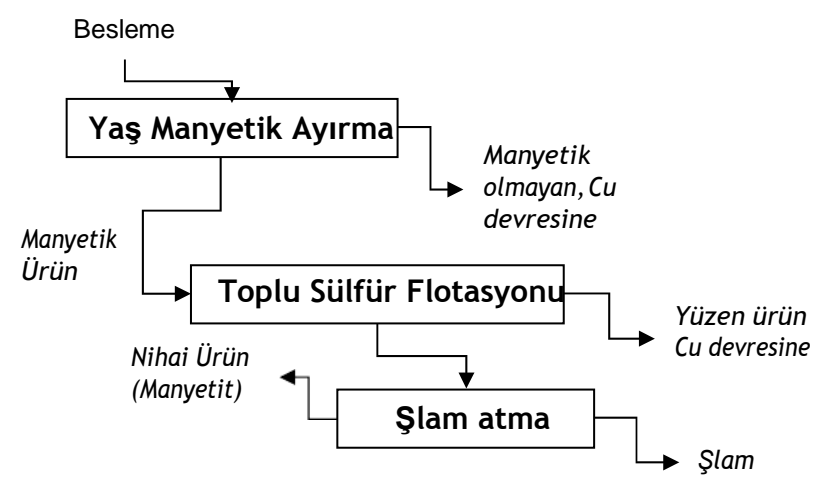

Şekil 6. $d_{90=} 75 \mu \mathrm{m}$ ve $d_{90=} 53 \mu$ m'a öğütülmüş numunelere uygulanan testlerin şematik görünümü. Figure 6. Schematic view of the tests applied to the samples ground to $d_{90}=75 \mu \mathrm{m}$.

Manyetik konsantresindeki kükürdün düşürülebilmesi amacıyla manyetik ayırma+toplu sülfür flotasyonu, $d_{90}=75$ ve $53 \mu \mathrm{m}$ inceliklere öğütülmüş olan numunelere ayrı ayrı uygulanmıştır. Manyetik konsantrelere uygulanan toplu flotasyonda, manyetik ayırma sırasında meydana gelen yüzey oksidasyonunu azaltmak için $250 \mathrm{~g} / \mathrm{t} \mathrm{Na}_{2} \mathrm{~S}$ kullanılmıştır. Toplayıcı olarak potasyum amil ksantat (KAX) ve köpürtücü olarak $D O_{250}(p p g)$ kullanılmıştır. Bu sayede hem bakır kaçağı hem de manyetit konsantresinin kükürt ve bakır içeriğinin azaltılması planlanmıştır. Mineralojik karakterizasyonda görüldüğü üzere killeşme cevher yapısında önemli bir etki göstermektedir. Bu nedenle flotasyondan sonra ürün içinden kabaca şlam atımı gerçekleştirilmiştir.

Ana cevher numunesi ve manyetik ayırma atık numunesi kullanılarak gerçekleştirilen flotasyon testlerinde ise, cevherde bulunan bakır minerallerinin flotasyon davranımlarını incelemek amacıyla aşağıdaki parametrelerin etkisi incelenmiştir:

- flotasyon besleme malzemesinin inceliği

- $\mathrm{pH}$

- farklı toplayıcıların etkisi

- $\quad$ sülfidizasyonun etkisi

\section{SONUÇLARIN DEĞERLENDIRILMESI}

\section{Düşük Alan Şiddetli Kuru Manyetik Ayırma Testleri (Cobbing)}

Düşük alan şiddetli kuru manyetik ayırma ürünlerinin demir, manyetit ve bakır içerikleri ile bunların verimleri Şekil 7'de verilmektedir. Şekil 7'de görüldüğü üzere, 10 
$\mathrm{mm}$ tane boyunda gerçekleştirilen testlerde birinci kademede \%33.91 Fe içeren, ikinci kademede ise \%45.02 Fe içeren atıklar ayrılabilmiş ve iki kademe sonunda alınan manyetik ürünün \%52.71 Fe içerdiği tespit edilmiştir. Bu tane boyunda verim son derece düşüktür ve temiz bir atık atılamamıştır. $-10 \mathrm{~mm}$ ile yapılan testlerde $\% 79.32$ verimle \%61.70 manyetit içeren bir ürün alınabilmektedir. Özellikle 900 gauss alan şiddetinde demir kaybı \%13.67 olurken, manyetit kaybı \%4.2 olarak ölçülmüştür. Bu durum cevherde manyetit dışında, manyetik alınganlığı manyetite göre daha düşük başka demirli minerallerin olduğu yönündeki bulguları doğrulamaktadır. Sonuçlar iri boylarda düşük alan şiddetli kuru manyetik ayırma ile bir ön zenginleştirmenin mümkün olamayacağını göstermektedir. Cevherdeki bakır açısından da iri boyda bir ön zenginleştirme sağlamak mümkün olmamaktadır.

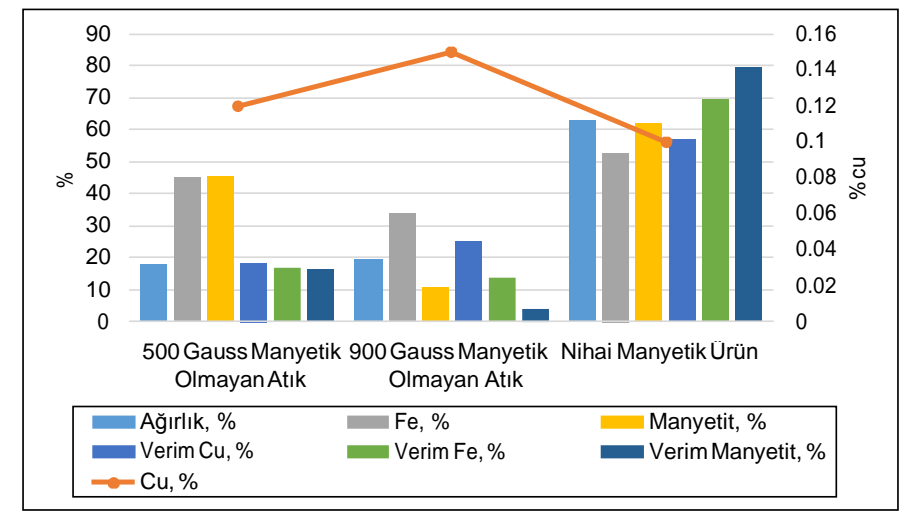

Şekil 7. Düşük alan şiddetli kuru manyetik tambur ürünlerinin özellikleri.

Figure 7. Properties of low-intensity dry magnetic separation products.

\section{Düşük Alan Şiddetli Yaş Manyetik Ayırma Testleri}

\section{Düşük alan şiddetli yaş manyetik ayırma testleri ile demir kazanımı}

Beş kademe manyetik ayırma ile $-500 \mu \mathrm{m},-300 \mu \mathrm{m}$ ve $-106 \mu \mathrm{m}$ tane boylarına öğütülmüş numunelere ayrı ayrı uygulanan düşük alan şiddetli yaş manyetik ayırma testlerinin demir ve manyetit içerikleri açısından sonuçları Şekil 8 a-f'de verilmiştir. Tüm testler açık devre olarak yapılmış ve temizleme atıkları da atık olarak ayrılmıştır.

Şekil 8 a ve b'de verilen $-500 \mu \mathrm{m}$ yaş manyetik ayırma ürünlerinin satmagan analizleri, manyetit içerikleri ve verimleri incelendiğinde; 900 Gauss ile yapılan birinci kademe manyetik ayırma işleminde \%61.9 manyetit içeren, ağırlıkça \%72.41 oranında alınan ürüne karşılık \%1.2 manyetit içeren, ağırlıkça \%27.59 manyetik 
olmayan atık uzaklaştırılabildiği görülmektedir. İlk kademenin manyetik ürününü temizlemek amacıyla 600 Gauss alan şiddetinde uygulanan ikinci kademe manyetik ayırmada ağırlıkça \%5.09 oranında ve \%1.9 manyetit içeren bir ürün atılırken, manyetik ürünün manyetit içeriği \%64.80'e yükselmektedir. Bu aşamada da önemli ölçüde safsızlık ayrılmaktadır. 600 Gauss'da manyetik ayırma işlemini takiben yapılan 400 Gauss ve 250 Gauss temizleme sonucunda \%69.80 manyetit içeren manyetik ürünün \%96.63 verimle alınabildiği görülmektedir. -500 $\mu \mathrm{m}$ ile yapılan test çalışması sonucunda beslemenin ağırlıkça \% 60.57'sine karşılık gelen bir manyetik ürün ve her bir temizleme kademesinde alınan atıkların toplamı olan ağırlıkça \% 39.43 miktarında bir manyetik olmayan ürün elde edilmiştir. Tamamı $-500 \mu \mathrm{m}$ tane boyuna indirilmiş numune ile yapılan yaş manyetik ayırma testlerinde 250 Gauss alan

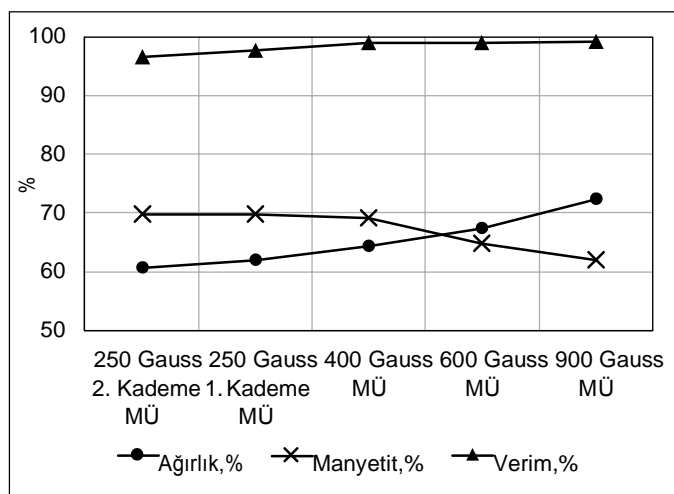

(a)

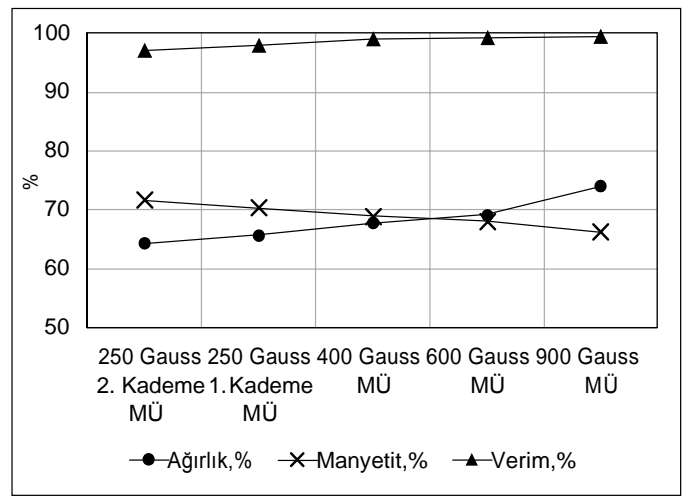

(c)

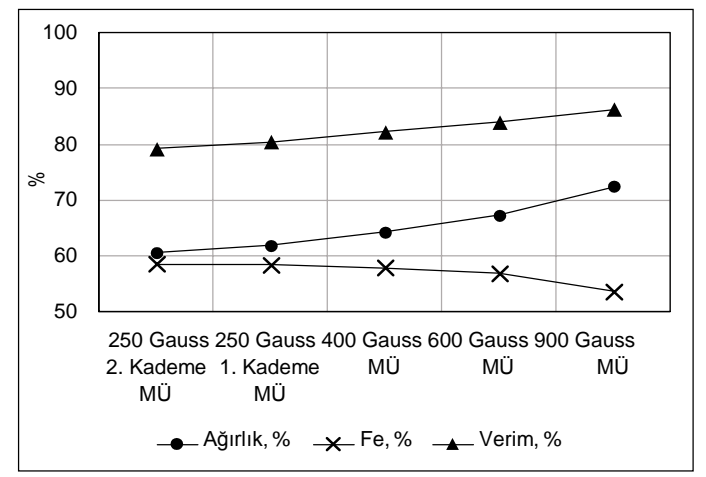

(b)

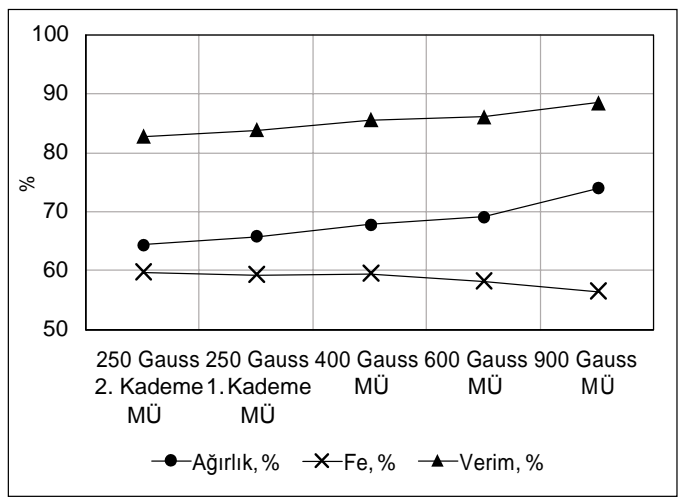

(d) 


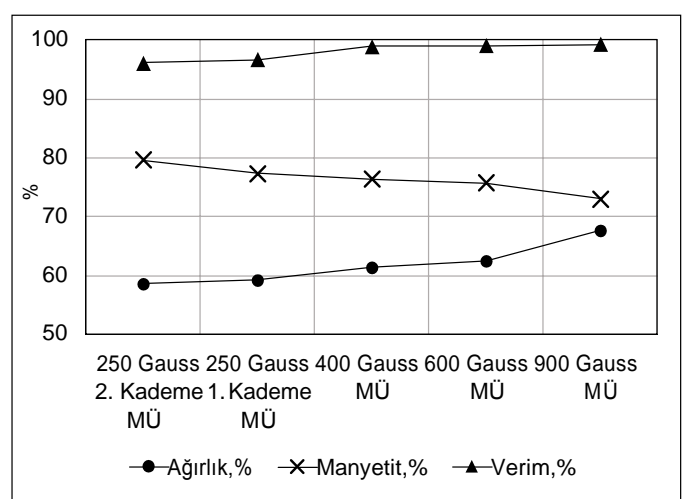

(e)

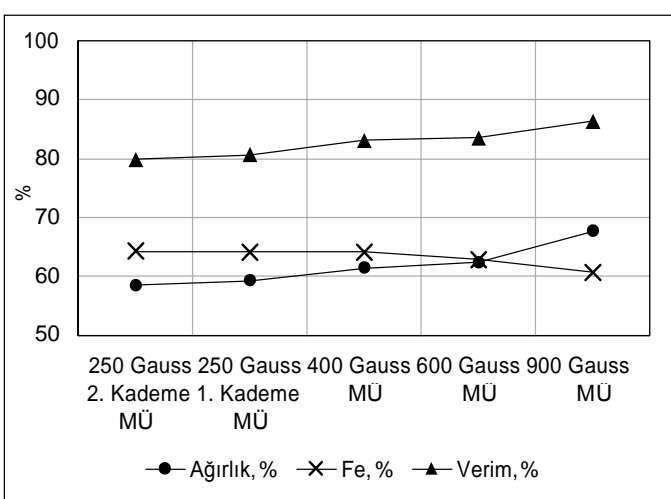

(f)

Şekil 8. $-500(a, b),-300(c, d)$ ve $-106(e, f) \mu m$ tane boyu ile yapılan yaş manyetik ayırma ürünlerinin Fe ve manyetit içerikleri ve verimleri (MÜ: manyetik ürün).

Figure 8. Fe and magnetite contents and yields of wet magnetic separation tests performed with -500 (a, b), -300 (c, d) and -106 (e, f) $\mu m$ feeds (MÜ: magnetic product).

şiddetinde yapılan son kademe temizleme sonucunda \%58.55 Fe içeren manyetik ürünün \% 79.19 Fe verimi ile alınabildiği görülmektedir. Bu tane boyunda beslemedeki toplam demirin \%20.81'i atığa gitmektedir. Manyetit verimi beş kademe temizlemeden sonra dahi \%96'nın üzerinde olurken demir (Fe) açısından bakıldığında son kademe temizleme aşamasından sonra demir verimi \%79.19 olarak belirlenmiştir. Bu durum geri dönecek akışlarla demir kazanımı lehinde olabilecektir. Fakat nihai ürünün Fe içeriği \%58.55 değerinde kalmaktadır. Bu da impüritelerin bu boyda yeterince uzaklaştırılamadığını göstermektedir.

-300 $\mu \mathrm{m}$ inceliğe öğütülmüş numune ile yapılan manyetik ayırma test sonuçları Fe ve manyetit kazanımı açısından Şekil 8 c ve d'de incelenmiştir. Tamamı -300 $\mu$ m tane boyuna indirilen numune ile yapılan yaş manyetik ayırma testlerinde 250 Gauss alan şiddetinde yapılan beşinci kademe temizleme sonucunda \%71.60 manyetit içeren manyetik ürünün \%97.08 verimle alınabildiği görülmektedir. -300 $\mu \mathrm{m}$ ile yapılan test çalışması sonucunda beslemenin ağırlıkça \%64.31'ini oluşturan bir manyetik ürün ve her bir temizleme kademesinde alınan atıkların toplamı olan ağırlıkça \%35.69 miktarında bir manyetik olmayan atık elde edilmiştir. Bu tane boyunda beslemedeki toplam manyetitin \%2.92'si atığa gitmektedir. Manyetit minerali kazanımı açısından sorun olmadığı görülmektedir. 250 Gauss alan şiddetinde yapılan son kademe temizleme sonucunda \%59.69 Fe içeren manyetik ürünün \%82.73 verimle alınabildiği 
görülmektedir. Bu tane boyunda beslemedeki toplam demirin \%17.27'si atığa gitmiştir. Besleme tane boyunun incelmesi ile hem verim artışı olmuş hem de \%Fe tenörü artmış, yaklaşık olarak \%60 değerine yükselmiştir.

-106 $\mu \mathrm{m}$ inceliğe öğütülmüş cevher ile yapılan testlerin sonuçları Şekil 8 e ve f'de verilmektedir. Tamamı -106 $\mu \mathrm{m}$ tane boyuna indirilen numune ile yapılan yaş manyetik ayırma testlerinde 250 Gauss alan şiddetinde yapılan son kademe temizleme sonucunda \%79.60 manyetit içeren manyetik ürünün \%96.15 verimle alınabildiği görülmektedir. -106 $\mu$ m ile yapılan test çalışması sonucunda beslemenin ağırlıkça \%58.51'ini oluşturan bir manyetik ürün ve her bir temizleme kademesinde alınan atıkların toplamı olan ağırlıkça \%41.49 miktarında manyetik olmayan atık elde edilmiştir. $\mathrm{Bu}$ tane boyunda beslemedeki toplam manyetitin \% 3.85 ’i atığa kaçmaktadır. Yine tamamı -106 $\mu \mathrm{m}$ tane boyuna indirilen numune ile yapılan yaş manyetik ayırma testlerinde 250 Gauss alan şiddetinde yapılan son kademe temizleme sonucunda \%64.21 Fe içeren manyetik ürünün \%79.90 verimle alınabildiği görülmektedir. Bu tane boyunda beslemedeki toplam demirin \%20.10'u atığa gitmiştir. Diğer testlerde olduğu gibi bu test de açık devre olarak yapılmış yani, temizleme atıkları bir önceki kademeye devrettirilmemiştir. Burada önemli olan nokta manyetik konsantrenin demir içeriğinin \%64 Fe değerinin üzerinde olmasıdır. Tüm tane boyları için, temizleme aşamalarında atıklar bir önceki aşamaya döndürülebilir. Tüm tane boylarında beslemedeki toplam manyetitin yaklaşık \%3-4'ü atığa kaçmaktadır (Şekil 9).

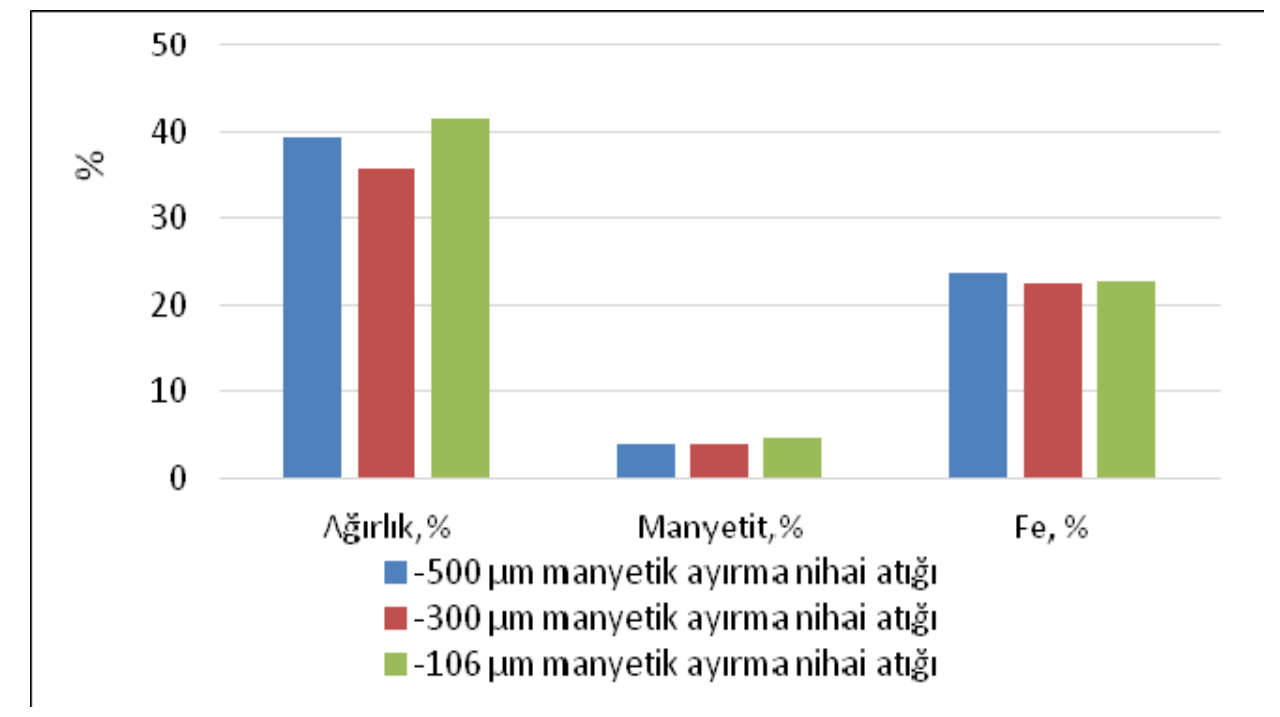

Şekil 9. Tüm tane boylarında, beslemedeki toplam manyetitin atıklara dağılımı.

Figure 9. Distribution of total magnetite to feed in all particle sizes. 
Şekil 10'da verilen besleme tane boyuna bağlı tenör verim ilişkisi incelendiğinde, özellikle cevherin ince boylara öğütülmesiyle demir tenörünün önemli ölçüde artabileceği görülmektedir. Bu ilişki cevherin demir kazanımı açısından ince boylara öğütülmesi gerekliliğinin en önemli göstergelerinden birisidir. Manyetik ayırma testleri sonucunda $\mathrm{Al}_{2} \mathrm{O}_{3}, \mathrm{~S}, \mathrm{MgO}$ gibi impüritelerin düşürülmesi için $106 \mu$ m'den ince boylarda zenginleştirme yapılmasının uygun olduğu görülmektedir.

Nihai demir konsantresinin impürite içeriklerini incelemek amacıyla $-500 \mu m,-300 \mu m$ ve $-106 \mu m$ tane boyuna öğütülmüş olan numunelerden elde edilmiş nihai manyetik konsantrenin detaylı kimyasal analizleri yapılmıştır. Çizelge 2'de verilen bu analizler incelendiğinde nihai ürünün hem kükürt içeriği hem de alümina içeriğinin ince tane boylarında düştüğü görülmektedir. Manyetik ayırma testleri sonunda mineralojik bulgularla uyumlu test sonuçları elde edilmiştir. Cevherin $106 \mu$ m'nin altına öğütülmesi ile nihai ürün Fe içeriği \%65 gibi bir seviyeye çıkartılabilirken özellikle

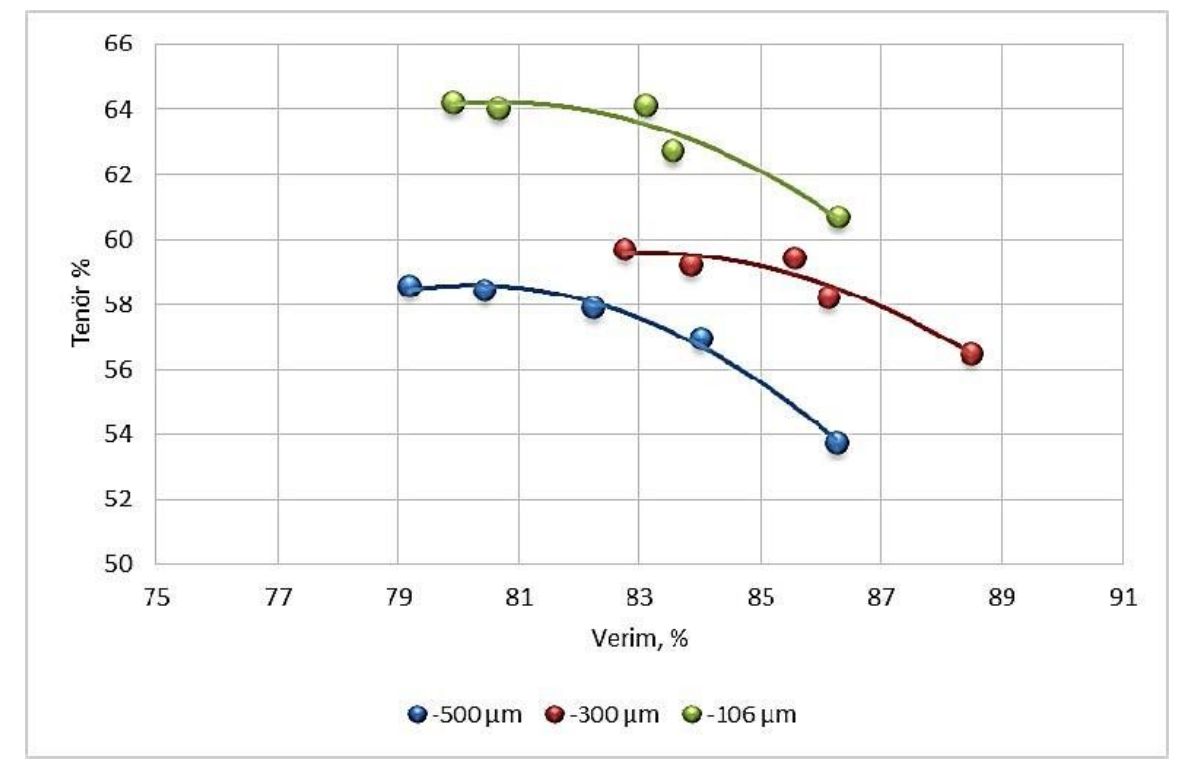

Şekil 10. Farklı inceliklerde manyetik ayırma testi tenör-verim ilişkisi.

Figure 10. Magnetic separation grade-recovery relation of different particle fineness.

kükürt ve alümina içerikleri açısından sorunların bu incelikte dahi devam ettiği anlaşılmaktadır. 


\begin{tabular}{|l|c|c|c|}
\hline Nihai konsantre tane boyu & $106 \mu$ & $300 \mu$ & $500 \mu$ \\
\hline $\mathrm{Al}, \%$ & 1.23 & 1.35 & 1.38 \\
\hline $\mathrm{Al}_{2} \mathrm{O}_{3}, \%$ & 2.32 & 2.55 & 2.61 \\
\hline $\mathrm{Fe}, \%$ & 64.21 & 59.69 & 58.55 \\
\hline $\mathrm{K}, \%$ & 0.03 & 0.04 & 0.04 \\
\hline $\mathrm{Mg}, \%$ & 0.78 & 1.11 & 1.19 \\
\hline $\mathrm{MgO}, \%$ & 1.3 & 1.85 & 1.98 \\
\hline $\mathrm{P}, \%$ & 0.02 & 0.06 & 0.07 \\
\hline $\mathrm{S}, \%$ & 0.39 & 1.26 & 1.59 \\
\hline $\mathrm{Cu}, \mathrm{ppm}$ & 226 & 531 & 593 \\
\hline
\end{tabular}

Çizelge 2. Farklı inceliklerde yapılmış olan manyetik ayırma testleri sonucu üretilen konsantrelerin genel bileşimi $(-106 \mu \mathrm{m},-300 \mu \mathrm{m},-500 \mu \mathrm{m})$.

Table 2. The general composition of the resulting magnetic separation concentrates (-106 $\mu \mathrm{m},-300 \mu \mathrm{m},-500 \mu \mathrm{m})$.

\section{Düşük alan şiddetli yaş manyetik ayırma testleri ile bakır kazanımı}

Düşük alan şiddetli yaş manyetik ayırma testlerinin bakır içerikleri açısından sonuçları Şekil 11 a, b ve c'de verilmiştir.

-500 $\mu \mathrm{m}$ tane boyu ile yapılan yaş manyetik ayırma testlerinde, beslemede $\% 0.13$ değerinde olan bakır ilk kademe manyetik ayırma atığında hemen hemen iki katına çıkarak \%0.223 değerine ulaşmaktadır (Şekil 11a). Manyetik ayırmanın ilk aşamasında ayrılan manyetik üründe ise bakır tenörü \%0.097 değerine düşmüştür. Temizleme aşamalarında da bir miktar bakır atık akışına yönelmiştir. Bu boyda beş

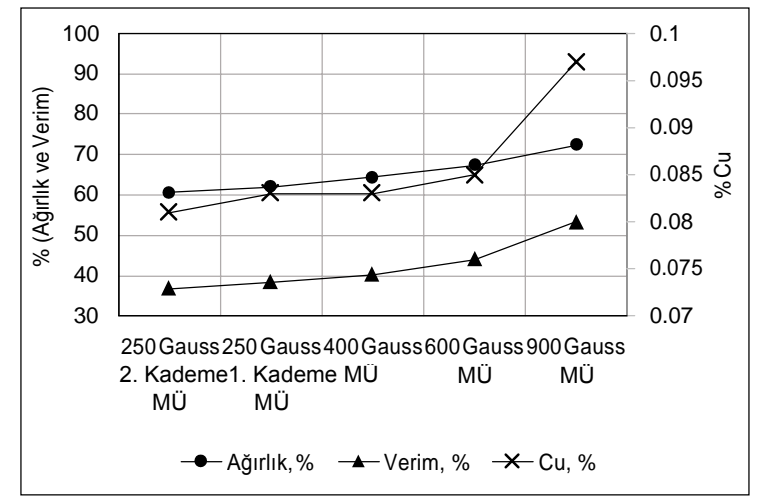

(a)

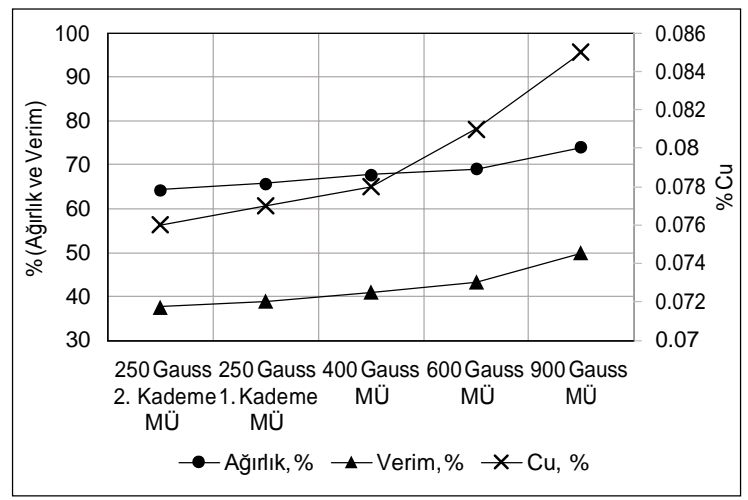

(b) 


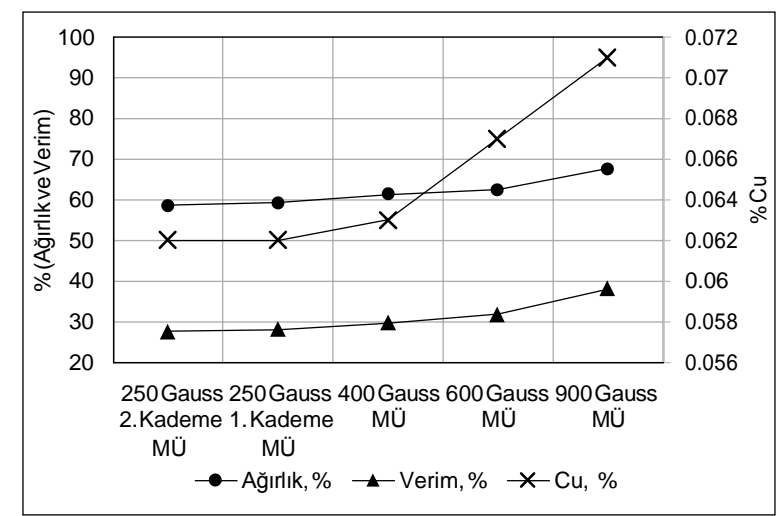

(c)

Şekil 11. $-500,-300$ ve $-106 \mu \mathrm{m}$ tane boyu ile yapılan yaş manyetik ayırma testi ürünlerinin bakır içerikleri ve verimleri.

Figure 11. Copper contents and yields of wet magnetic separation test products performed with $-500,-300$ and $-106 \mu \mathrm{m}$ feed samples.

kademe temizleme sonrasında beslemedeki bakırın \%63.22'si manyetik ürün içinden atığa ayrılabilmiştir.

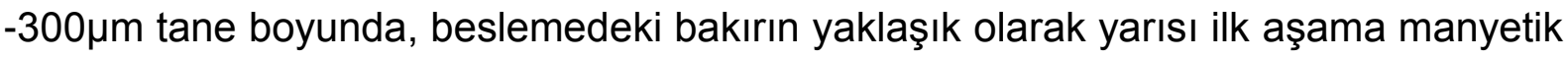
ayırma sonunda manyetik üründen ayrılmakta ve atığa geçmektedir (Şekil 11b). İlk aşama manyetik ayırma sonunda dahi manyetik üründe kalan bakır tenörü \%0.085 seviyesinde olmaktadır. Daha sonraki temizleme aşamalarında da manyetik üründe kalan bakırın önemli bir bölümü atığa gönderilebilmiştir. Beş aşama manyetik ayırma sonunda beslemedeki bakırın \%62.39'u manyetik üründen ayrılabilirken \%37.61'i hala manyetik üründe kalmaktadır. Bu da manyetik üründe bakır tenörünün \%0.076 seviyesinde kalmasına neden olmuştur.

Düşük alan şiddetli manyetik ayırma testlerinde besleme tane boyu -106 $\mu$ m'nin altına indiğinde, manyetik üründe kalan bakır, ayırıma giren toplam bakırın \%27.77'sidir (Şekil 11c). Bu durum bir önceki boyda yapılan ayrım ile kıyaslandığında tane boyu inceldikçe bakırın manyetik üründen daha etkili bir şekilde ayrılabileceğini göstermektedir. Beslemedeki bakırın \%72.23'ü manyetik ayırma devresi atık akışına geçmiştir. Buna rağmen bu boyda dahi nihai manyetik ürünün içinde $\% 0.062$ seviyesinde bakır kalmaktadır.

Manyetik ayırma işlemi ile cevher içindeki $\mathrm{Cu}$ içeriği yaklaşık \%0.13 değerinden \%0.23 değerine kadar çıkartılabilmiştir. Ağırlık olarak değerlendirildiğinde cevherin 
\%60 düzeyinde manyetik ürüne ayrılacağı göz önüne alınırsa, toplam beslemenin ağırlıkça \%40'ından fazlası bakır içeriği açısından orijinale göre iki kat daha zengin olarak bakır flotasyon devresine verilebilir.

Sonuçlar, manyetik ayırma atığının bakır flotasyonuna tabi tutulması ve hatta manyetit konsantresinin de tekrar bakır flotasyonuna tabi tutulması gerektiğini göstermiştir. Bu şekilde hem manyetik ürüne kaçan bakır belirli oranlarda kazanılabilir, hem de nihai manyetik ürünün kükürt içeriği biraz daha düşürülebilir. Bu nedenle nihai manyetik konsantresine toplu sülfür flotasyon testleri uygulanmıştır. Daha ince boylara inilmesinin hem demir devresinde hem de bakır devresinde performans artışına neden olabileceği göz önüne alınarak daha ince boylarda flotasyon çalışmalarına devam edilmiştir.

Tüm tane boylarında, beslemedeki toplam bakırın atığa kaçan miktarları Şekil 12'de verilmektedir.

\section{Yüksek Alan Şiddetli Manyetik Ayırma ile Kalite Artırmaya Yönelik Testler}

Düşük alan şiddetli manyetik ayırma işleminde demir (Fe) kaybı \%15-20 arasında olmaktadır. Bu kayıp, sadece demir oksitler yüzünden değil aynı zamanda atığa giden pirit $\left(\mathrm{FeS}_{2}\right)$ içindeki demirden de kaynaklanmaktadır. Bu kayıplardan demir kazanımını incelemek amacıyla düşük alan şiddetli yaş manyetik ayırma sonrasında manyetik olmayan kısma giden atık yüksek alan şiddetli, yaş, matriks tipi ayırıcıyla manyetik ayırma işlemine tabi tutulmuştur. Uygulanan testin şeması Şekil 13'de verilmektedir. Bu işlemde yüksek alan şiddetli yaş manyetik ayırıcıya giren malzemenin (düşük alan şiddetli manyetik ayırma atığı) ağılıkça \%58.06'sı ürün olarak alınabilmiştir (Çizelge 3). Bu ürün $0.8 \mathrm{~T}$ gibi görece düşük bir alan şiddetinde temizleme aşamasında alınmasına rağmen $\mathrm{SiO}_{2}$ içeriği \%15.98, $\mathrm{Al}_{2} \mathrm{O}_{3}$ içeriği \%4.00 gibi oldukça yüksek değerlerde kalmaktadır. Demir içeriği ise \%36.46 olarak orijinal cevher beslemesinin de altında kalmaktadır. İki aşama yüksek alan şiddetli manyetik ayırma işleminde dahi bu değerlere ulaşılabilmesi, düşük alan şiddetli manyetik ayırma atığın da bulunan demirin satılabilir bir şekilde kazanılamayacağını göstermektedir. 


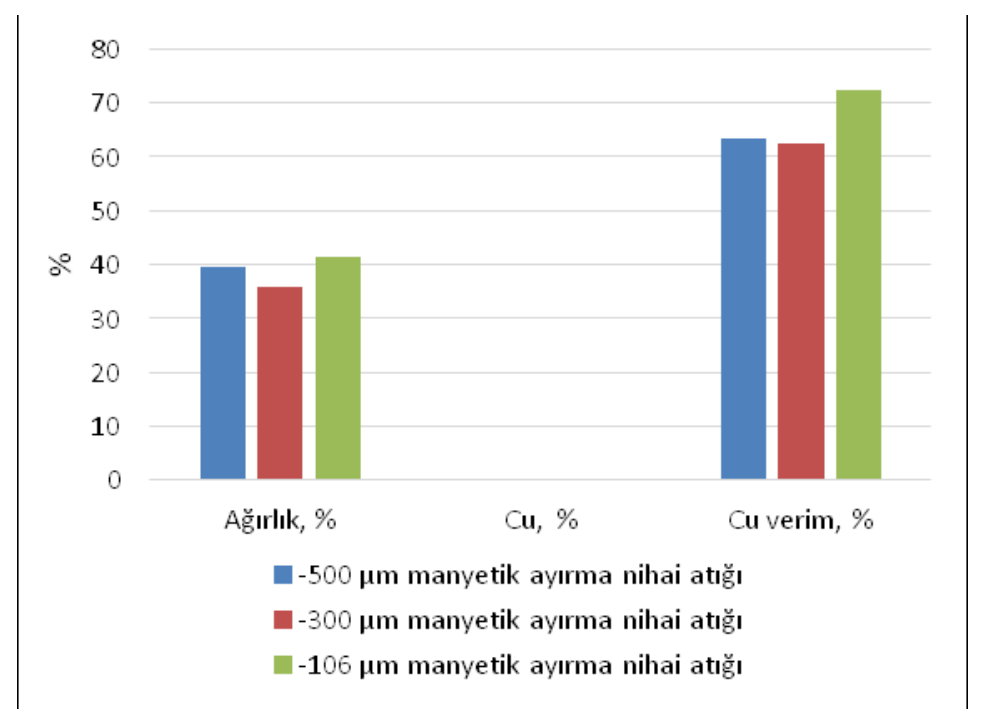

Şekil 12. Tüm tane boylarında, beslemedeki toplam manyetitin atıklara dağılımı.

Figure 12. Distribution of total magnetite from feed to in all particle sizes.

\begin{tabular}{|c|c|}
\hline & Atıktan ayrılabilen nihai manyetik ürün \\
\hline Miktar \% & 58.06 \\
\hline$\% \mathrm{Fe}$ & 36.46 \\
\hline$\% \mathrm{SiO}_{2}$ & 15.98 \\
\hline$\% \mathrm{Al}_{2} \mathrm{O}_{3}$ & 4.00 \\
\hline$\% \mathrm{CaO}$ & 8.80 \\
\hline$\% \mathrm{MgO}$ & 5.33 \\
\hline$\% \mathrm{~K}_{2} \mathrm{O}$ & 0.17 \\
\hline$\% \mathrm{Na}_{2} \mathrm{O}$ & 0.03 \\
\hline$\% \mathrm{P}$ & 0.21 \\
\hline$\% \mathrm{~S}$ & 1.63 \\
\hline$\% \mathrm{Cu}, \mathrm{ppm}$ & 1120 \\
\hline & \\
\hline
\end{tabular}

Çizelge 3. Atığa uygulanan yüksek alan şiddetli yaş manyetik ayırma işlemi sonucu alınan ürünün kimyasal içeriği.

Table 3. Chemical content of the product obtained after high intensity wet magnetic separation applied to the waste. 


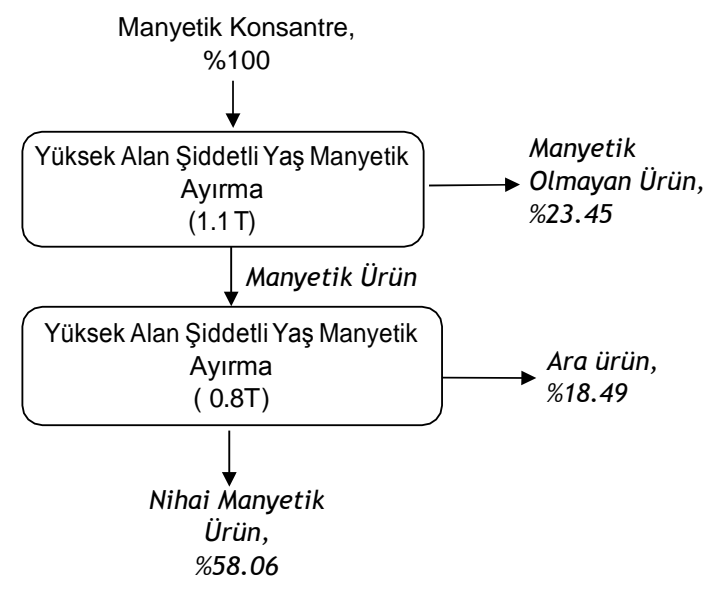

Şekil 13. Düşük alan şiddeti manyetik ayırma atığına uygulanan yüksek alan şiddetli manyetik ayırma işlemi sonucunda alınan ürünler.

Figure 13. Products of high intensity magnetic separation applied to low intensity magnetic separation products.

\section{Bakır Kazanımı ve Kalite Artışına Yönelik Flotasyon Testlerinin Sonuçları}

Manyetik ayırma testlerinde -106 $\mu \mathrm{m}$ incelikte dahi nihai ürünün kükürt içeriğinin \%0.38 seviyesinde kaldığı görülmektedir. Bu sebeple manyetik ayırma ürünü ile toplu sülfür flotasyonu testleri gerçekleştirilmiştir. Manyetik konsantrelere uygulanan toplu flotasyon sonuçları Çizelge 4 'de verilmektedir. $d_{90}=75 \mu \mathrm{m}$ ve $53 \mu \mathrm{m}$ inceliklere öğütülmüş olan numunelere ayrı ayrı uygulanan flotasyon sonucunda manyetik konsantrenin bakır içeriği \%0.01 $\mathrm{Cu}$ değerine kadar azaltılabilmiştir. Manyetit konsantresindeki bakırın \%44'ü, \%0.37 tenörlü bir konsantre olarak ayrılabilmektedir.

\begin{tabular}{|c|c|c|c|c|c|c|}
\cline { 2 - 7 } \multicolumn{1}{c|}{} & \multicolumn{3}{c|}{$\mathrm{d} 90=75 \mu \mathrm{m}$} & \multicolumn{3}{c|}{$\mathrm{d} 90=53 \mu \mathrm{m}$} \\
\cline { 2 - 7 } & $\begin{array}{c}\text { Yüzen } \\
\text { Ürün 1 }\end{array}$ & $\begin{array}{c}\text { Yüzen } \\
\text { Ürün 2 }\end{array}$ & $\begin{array}{c}\text { Manyetik } \\
\text { Konsantre }\end{array}$ & $\begin{array}{c}\text { Yüzen } \\
\text { Ürün 1 }\end{array}$ & $\begin{array}{c}\text { Yüzen } \\
\text { Üün 2 }\end{array}$ & $\begin{array}{c}\text { Manyetik } \\
\text { Konsantre }\end{array}$ \\
\hline$\%$ Ağırlık & 1.85 & 0.55 & 97.6 & 1.27 & 0.34 & 98.39 \\
\hline$\% \mathrm{Cu}$ & 0.37 & 0.37 & 0.01 & 0.28 & 0.16 & 0.01 \\
\hline$\%$ Cu verim & 34.29 & 9.98 & 55.74 & 27.26 & 4.22 & 68.53 \\
\hline$\%$ Birikimli Cu & 0.37 & 0.37 & & 0.28 & 0.26 & \\
\hline \% Birikimli Cu verim & 34.29 & 44.26 & & 27.26 & 31.47 & \\
\hline
\end{tabular}

Çizelge 4. $d_{90}=75 \mu \mathrm{m}, d_{90}=53 \mu \mathrm{m}$ incelikler için manyetik ayırma + flotasyon + şlam atma test sonucu bakır kazanımı.

Table 4. Copper recovery test result of magnetic separation + flotation + desliming for finenesses of $d_{90}=75 \mu \mathrm{m}$ and $d_{90}=53 \mu \mathrm{m}$. 
$d_{90}=75$ ve $53 \mu \mathrm{m}$ boylarında uygulanmış olan zenginleştirme sonucunda ürünlerin genel bileşimleri Çizelge 5 'de verilmektedir. $d_{90}=75 \mu \mathrm{m}$ inceliğe öğütülmüş olan cevherle yapılan test sonucunda manyetik ayırma ile \%65'in üzerinde Fe içeren bir konsantre elde edilmiştir. Fakat bu ürünün $\mathrm{SiO}_{2}$ içeriği \%3.04 olmuştur. Kükürt içeriği (S) ise \%0.38 seviyesindedir. Bu nedenle bu ürüne toplu sülfür flotasyonu uygulanmış ve bunun sonucunda $\mathrm{SiO}_{2}$ ve $\mathrm{Al}_{2} \mathrm{O}_{3}$ içeriğinde önemli bir değişiklik olmazken kükürt içeriği \%0.06 gibi satış sorunu yaratmayacak değerin altına düşürülebilmiştir. Flotasyon kükürt içeriğinde önemli oranda bir düşüş sağlamaktadır. Flotasyon sonrası manyetik konsantrede kalan silikatların uzaklaştırılması amacıyla flotasyon konsantresine şlam atımı uygulanmıştır. $d_{90}=53 \mu \mathrm{m}$ inceliğe öğütülmüş olan cevherle yapılan test sonucunda ana beslemenin \%57.6'sı \%65.86 Fe, \%2.53 $\mathrm{SiO}_{2}, \% 2.19 \mathrm{Al}_{2} \mathrm{O}_{3}$ ve \%0.02 S içeren bir ürün olarak alınabildiğigörülmüştür.

\begin{tabular}{|c|c|c|c|c|c|c|}
\hline & $\begin{array}{c}-75 \mu \mathrm{m} \\
\mathrm{MAK}^{*}\end{array}$ & $\begin{array}{c}-75 \mu \mathrm{m} \\
\text { MAK-FS }\end{array}$ & $\begin{array}{c}-75 \mu \mathrm{m} \\
\text { MAK-FS-ŞA* }\end{array}$ & $\begin{array}{l}-53 \mu \mathrm{m} \\
\mathrm{MAK}^{*}\end{array}$ & $\begin{array}{c}-53 \mu \mathrm{m} \\
\text { MAK-FS* }\end{array}$ & $\begin{array}{c}-53 \mu \mathrm{m} \\
\text { MAK-FS-ŞA* }\end{array}$ \\
\hline Ağırlık, \% & 61.68 & 58.3 & 57.6 & 59.39 & 55.9 & 55.2 \\
\hline$\% \mathrm{Fe}$ & 65.61 & 65.45 & 65.86 & 65.7 & 65.6 & 66.47 \\
\hline$\% \mathrm{SiO}_{2}$ & 3.04 & 3.17 & 2.53 & 2.28 & 2.3 & 1.44 \\
\hline$\% \mathrm{Al}_{2} \mathrm{O}_{3}$ & 2.01 & 2.08 & 2.19 & 1.6 & 1.62 & 1.46 \\
\hline$\% \mathrm{CaO}$ & 1.22 & 1.26 & 1.1 & 0.81 & 0.83 & \\
\hline$\% \mathrm{MgO}$ & 1.07 & 1.11 & 1.2 & 0.9 & 0.99 & 0.75 \\
\hline$\% \mathrm{Mn}$ & 0.12 & 0.14 & 0.11 & 0.13 & 0.14 & \\
\hline$\% \mathrm{~K}_{2} \mathrm{O}$ & 0.06 & 0.05 & 0.04 & 0.04 & 0.03 & \\
\hline$\% \mathrm{Na}_{2} \mathrm{O}$ & 0.062 & 0.063 & 0.05 & 0.07 & 0.061 & \\
\hline$\% \mathrm{P}$ & 0.022 & 0.019 & 0.01 & 0.011 & 0.007 & \\
\hline$\% \mathrm{~S}$ & 0.38 & 0.06 & 0.02 & 0.19 & 0.11 & 0.02 \\
\hline$\% \mathrm{Cu}$ & 0.015 & 0.015 & 0.011 & $0.009-0.01$ & 0.008 & \\
\hline
\end{tabular}

Çizelge $5 . \mathrm{d}_{90}=75$ ve $-53 \mu \mathrm{m}$ manyetik ayırma+flotasyon+şlam atma test sonucu.

Table 5. Overall test result of magnetic separation + flotation + desliming for finenesses of $d_{90}=75 \mu \mathrm{m}$ and $d_{90}=53 \mu \mathrm{m}$.

$\mathrm{d}_{90=} 75 \mu \mathrm{m}$ tane boyunda şlam atma işleminden sonra dahi elde edilen nihai ürünün $\mathrm{Al}_{2} \mathrm{O}_{3}$ ve $\mathrm{MgO}$ içeriği sırasıyla $\% 2.19$ ve \%1.20 düzeyinde kalmaktadır. Ayrıca manyetik ayırma atıklarına bu boyda $\left(\mathrm{d}_{90}=75 \mu \mathrm{m}\right)$ uygulanan bakır flotasyonu testlerinde konsantre verim ve tenörünün düşük olması nedeniyle daha ince boyda bakır kazanımını tespit etmek amacıyla cevher $d_{90}=53 \mu$ m'a öğütülmüştür. $d_{90}=53 \mu \mathrm{m}$ inceliğindeki cevhere de beş kademe yaş manyetik ayırma uygulandıktan sonra elde 
edilen manyetik konsantreye toplu sülfür flotasyonu uygulanmıştır. Buradan elde edilmiş olan ürünün de şlamı uzaklaştırılarak nihai manyetik ürün alınmıştır. Temizleme atıkları sisteme geri döndürülmemiştir. Nihai üründe demir içeriği \%65'in üzerine çıkarken kükürt içeriğinin de \%0.1'in altına düşürülebildiği görülmüştür.

$\mathrm{Bu}$ sonuçlar doğrultusunda cevherden manyetik ürün elde edilebilmesi amacıyla öğütme inceliğinin $\left(\mathrm{d}_{90}\right) 53 \mu \mathrm{m}$ olacak şekilde ayarlanması nihai ürün kalitesi açısından önem taşımaktadır. Hem bakır kaçağı hem de manyetit konsantresinin kükürt ve bakır içeriği önemli oranda azaltılabilmiştir. Mineralojik karakterizasyon bölümünde bahsedildiği gibi killeşme cevher yapısında önemli bir etki göstermektedir. $\mathrm{Bu}$ nedenle manyetik ayırmayı takip eden flotasyon sonunda üründe bir miktar kil kalmış ve bu da nihai ürünün $\mathrm{Al}_{2} \mathrm{O}_{3}$ içeriğinin yüksek kalmasına neden olmuştur. $\mathrm{Bu}$ nedenle flotasyondan sonra ürün içinden kabaca şlam atımı şeklinde killer uzaklaştırılmıştır.

Bakır kazanımına yönelik testler ise orijinal cevher numunesi ve manyetik ayırma atık numunesi kullanılarak gerçekleştirilmiştir. $\mathrm{Bu}$ testler kapsamında $\mathrm{pH}$, tane boyu, toplayıcı karışımları ve sülfidizasyonun bakır kazanımı üzerine etkileri incelenmiş ve cevher için ideal bakır kazanımı devresinin tanımlanması amaçlanmıştır.

Seçimli bakır flotasyonu için yaygın olarak kullanılan üç toplayıcının flotasyon performansına etkileri incelenmiştir. Bu toplayıcılar; Aerophine 3418A (dithiofosfin), Aero9863 (thionocarbamat), Aero3477 (dithiofosfat) olarak seçilmişlerdir. Bu toplayıcılara ek olarak, seçimliliği göreceli olarak daha düşük ancak kuvvetli bir toplayıcı olan KAX (potasyum amil ksantat) diğer toplayıcılarla karışım halinde kullanılmıştır. Toplayıcıların flotasyon performanslarının karşılaştırması kaba flotasyon verim ve tenörü üzerinden yapılmıştır (Çizelge 6). Elde edilen konsantrelerin tenör değerleri benzer olmasına karşın, en yüksek verim değeri Aero3477+KAX karışımı ile elde edilmiştir.

\begin{tabular}{|l|c|c|c|c|c|}
\cline { 2 - 6 } \multicolumn{1}{c|}{} & \multicolumn{3}{c|}{ Cevher Numunesi } & \multicolumn{2}{c|}{ Manyetik Ayırma Atık Numunesi } \\
\cline { 2 - 6 } \multicolumn{1}{c|}{} & 3418A & Aero9863 & Aero3477+KAX & $3418 \mathrm{~A}$ & 3418A+KAX \\
\hline \% Ağırık & 5.85 & 6.3 & 6.66 & 12.22 & 13.17 \\
\hline$\% \mathrm{Cu}$ & 0.97 & 0.98 & 0.93 & 1.07 & 1.01 \\
\hline \% Cu verim & 56.86 & 57.49 & 59.78 & 57.45 & 56.1 \\
\hline
\end{tabular}

Çizelge 6. Toplayıcı türü ve karışımlarının bakır flotasyonuna etkisi.

Table 6. Effect of collector species and mixtures on copper flotation. 
$\mathrm{d}_{90}=106 \mu \mathrm{m}$ ile $\mathrm{d}_{90}=53 \mu \mathrm{m}$ arasında olduğunda, flotasyon besleme inceliğinin flotasyon performansına önemli bir etkisinin olmadığı belirlenmiştir. Her üç tane boyunda da yaklaşık \%1 Cu tenörlü kaba flotasyon konsantresi \%56-57 verimle elde edilmiştir. Konsantreye taşınan malzemenin ağırlık verimi -106 $\mu \mathrm{m}$ tane boyunda \%12.22, diğer boylarda ise \%5.5-6 civarında olmuştur. Bu durum, -106 $\mu \mathrm{m}$ deneyinde manyetik ayırma atığı, diğer deneylerde ise cevher numunesinin flotasyon beslemesi olarak kullanılmasından kaynaklanmaktadır.

Cevherin bakır içeriği (\%0.1 Cu) çok düşük olduğundan, cevherin doğal pH'sında toplu sülfür flotasyonu yapılarak flotasyon verimi yükseltilmeye çalışılmıştır. Elde edilen kaba flotasyon konsantresi $\mathrm{pH} 11.5-12$ 'de temizleme işlemine tabi tutulmuştur. Bu deneye alternatif olarak, kaba flotasyon aşamasında $\mathrm{pH}$ 11.5-12 değerine kireç ile yükseltilerek seçimli bakır flotasyonu gerçekleştirilmiştir. Elde edilen sonuçlar flotasyon performansının her iki pH değeri için benzer olduğunu göstermiştir.

Çizelge 6'da görüldüğü üzere bakır veriminin en iyi koşullarda \%60 civarında olması, uzun süre bekletilmiş karot numunelerinden hazırlanan test numunesinin belli bir oranda oksitlenmiş olabileceği intimalini ortaya koymuştur. Oksitlenmiş sülfürlü mineral yüzeylerinin temizlenmesi amacıyla $250 \mathrm{~g} / \mathrm{t} \mathrm{Na}_{2} \mathrm{~S}$ öğütme aşamasında kullanılmıştır. Elde edilen sonuçlar sülfidizasyonun hem konsantre tenörü hem de verimini belli bir ölçüde artırdığını göstermiştir. Ancak, verim değeri \%61 değerine kadar artırılabilmiştir.

Gerçekleştirilen tarama deneylerinin ve kullanılan kimyasalların malzeme üzerindeki etkilerinin sonuçlarına dayanarak, akım şemasını geliştirme çalışmaları gerçekleştirilmiştir. Bu kapsamda yapılan deneylerde kaba flotasyon, süpürme flotasyonu ve temizleme flotasyonu aşamaları uygulanmıştır. Öncelikli olarak gerçekleştirilen baz koşullardaki (orijinal cevher ile gerçekleştirilen) 1 Numaralı Cu flotasyonu testinde, cevherde bulunan kilin flotasyona olumsuz etkisini gidermek amacıyla öğütme aşamasında değirmene $1 \mathrm{~kg} / \mathrm{t} \mathrm{Na}$-Silikat eklenmiştir. Öğütme işlemi doğal pH'da $(\mathrm{pH}=8)$, kaba flotasyon ise $\mathrm{pH}=11$ 'de gerçekleştirilmiştir. Toplayıcı olarak Aero3477+KAX karışımı kullanılmıştır. Kaba flotasyon konsantresi üç aşama temizleme flotasyonuna tabi tutulmuştur. Elde edilen sonuçlarda kaba flotasyon bakır 
verimi \%55 civarında olduğu ve üç kademe temizleme sonrasında yaklaşık \%12 Cu tenörlü bakır konsantresi elde edilebildiği görülmüştür. Cevherin bakır içeriği \%0.1 Cu gibi düşük bir değerde olduğundan, $3 \mathrm{~kg}$ besleme malzemesinden üçüncü temizleme konsantresinde yalnızca $2.6 \mathrm{gr}$ malzeme elde edilebilmiştir. Bu sebeple laboratuvar ölçekli deneylerde temizleme flotasyonunda aşama sayısının ve konsantre tenörünün artırılması 1 Numaralı test kapsamında mümkün olmamıştır. Fakat bu test kapsamında toplam bakır verimini artırmak amacıyla ek toplayıcı ilavesiyle süpürme flotasyonu uygulanmış ve \%5 verimle \%0.57 Cu tenörlü ek bir konsantre elde edilmiştir.

Bunu takip eden 2 Numaralı Cu flotasyonu testinde bakır veriminin artırılması için öğütme aşamasında $250 \mathrm{~g} / \mathrm{t} \mathrm{Na} \mathrm{Na}_{2} \mathrm{~S}$ eklenerek sülfidizasyon işlemi yapılmıştır. Kaba flotasyon ve temizleme flotasyonu aşamalarında da piritin daha etkin bir şekilde bastırılabilmesi için $\mathrm{Na}_{2} \mathrm{~S}_{2} \mathrm{O}_{5}$ ilavesi yapılmıştır. 2 Numaralı testlerden elde edilen sonuçlar, $\mathrm{Na}_{2} \mathrm{~S}_{2} \mathrm{O}_{5}$ eklemesinin konsantredeki bakır tenörünü artırdığını ancak kaba flotasyon bakır verimini düşürdüğünü göstermiştir. 2 Numaralı test kapsamında, üç aşama temizleme flotasyonu sonrasında bakır konsantresinin tenörü \%14.25 Cu değerine yükseltilebilmiştir.

Ek olarak, 2 Numaralı testte uygulanan kimyasal koşullar kullanılarak manyetik ayırma atığı ile de Cu flotasyonu testleri gerçekleştirilmiştir. Bu testlerde iki farklı akım şeması uygulanmıştır. Bunlardan akım şemalarının ilkinde kaba flotasyon ve süpürme flotasyon konsantreleri birleştirilerek dört aşamalı temizleme flotasyonuna tabi tutulmuştur. İlk kademe temizleme flotasyonunun atığına süpürme flotasyonu uygulanarak, mümkün olan en yüksek tenörlü konsantrenin en yüksek bakır verimiyle elde edilmesine amaçlanmıştır. Bu deneyden elde edilen sonuçlarda, kaba konsantre bakır veriminin \%58.5 olduğu ve bunun yaklaşık olarak \%9'unun Temizleme 1 atığına kaçtığı görülmüştür. Birinci temizleme aşamasına beslenen toplam malzemenin yaklaşık olarak \%50'si \%0.43 Cu tenörlü atık olarak atılmaktadır. Bu malzemenin tamamını kaba flotasyon aşamasına çevirmemek için birinci temizleme atığına toplayıcı ilave edilerek süpürme flotasyonu gerçekleştirilmiştir. Temizleme-Süpürme flotasyonuna beslenen bakırın \%63’ü \%0.59 Cu tenörlü konsantre olarak elde 
edilmiştir. Bu akım şemasında Temizleme-Süpürme konsantresi kaba flotasyon aşamasına geri çevrilirken, bakırın \%3.45'ini içeren atık akışı ise nihai atık olarak devreden uzaklaştırılabilecektir.

2 Numaralı testte uygulanan kimyasal koşullar kullanılarak manyetik ayırma atığı ile gerçekleştirilen akım şemalarının ikincisinde, bakır kaba flotasyon konsantresi temizleme işlemine tabi tutulmuş ve süpürme flotasyon konsantresi kaba flotasyon devresine çevrilecek şekilde ayrı bir konsantre olarak alınmıştır (Şekil 14). Bu ikinci akım şemasında ilk temizleme flotasyonu artığına süpürme flotasyonu uygulanmamıştır. Bu akım şemasında hem ilk temizleme atık hem de süpürme konsantresi kaba flotasyon devresine geri çevrilmiştir. İkinci akım şemasına uygun testler onucunda bakır kaba flotasyon konsantresinin tenörü \%4.43 Cu ile elde edilen en yüksek tenörlü konsantre olmuştur. Buna bağlı olarak, üç aşama temizleme flotasyonu sonrasında konsantre tenörü \%15 Cu değerinin üzerinde olmuştur. Kaba flotasyon ve süpürme flotasyonundan elde edilen toplam bakır verimi \%63.82 ile yine elde edilen en yüksek verim değeri olmuştur. Bu nedenle, gerçekleştirilen deneysel çalışmalar sonucunda elden edilen en iyi akım şeması ve ürünlerin dağılımı ile flotasyon koşulları Şekil 14, Çizelge 7 ve Çizelge 8'de verilmiştir.

Şekil 14 ve Çizelge 7'de verilen flotasyon verileri, flotasyon devresi madde denkliği ve simülasyon çalışmalarında kullanılmıştır. Kaba flotasyon ve süpürme flotasyonu aşamalarında en yüksek bakır verimi ve üç aşama temizleme flotasyonu sonrasında en yüksek konsantre tenörünün elde edildiği koşulun verileri kullanılarak, kapalı devre çalışılması durumunda elde edilecek verim ve tenör değerleri modellemesimülasyon yardımıyla hesaplanmıştır. Madde denkliği çalışmalarından elde edilen verim ve tenör değerleri kullanılarak her flotasyon aşaması için bakır ve safsızıkların flotasyon hız sabitleri hesaplanmıştır. Hız sabitleri ve laboratuvar deneylerinde kullanılan flotasyon süreleri baz alınarak temizleme atık akışları ve süpürme konsantresi geri çevrildiğinde elde edilecek verim ve tenör değerleri hesaplanmıştır. Simülasyon sonuçları Şekil 15'deki akım şemasında verilmiştir. Akım şemasında verilen lejantın sol üst kısmı deneyde kullanılan toplam malzeme miktarını, sağ üst kısmı tonajı \% bazında, sol alt kısmı bakır tenörünü ve sağ alt kısmı flotasyon 
devresine beslenen malzemedeki bakır miktarına göre hesaplanmış bakır verimini göstermektedir.
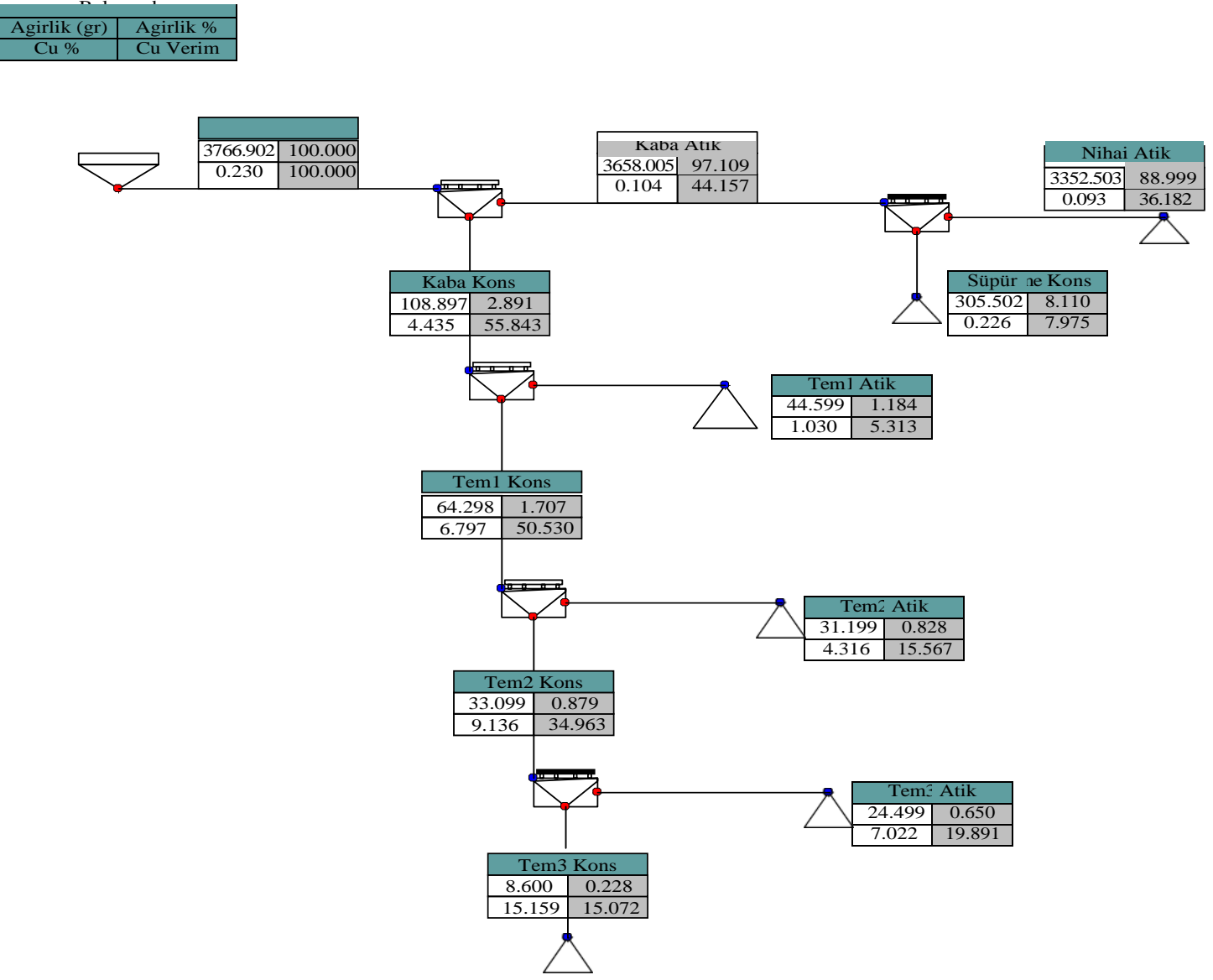

Şekil 14. Elde edilen en iyi bakır flotasyon devresi.

Figure 14. Best copper flotation circuit obtained.

\begin{tabular}{|c|c|c|}
\hline & $\mathrm{Cu} \%$ & Cu Verim \% \\
\hline Nihai atık & 0.09 & 36.47 \\
\hline Süpürme konsantresi & 0.20 & 8.04 \\
\hline Temizleme 1 atık & 1.02 & 5.28 \\
\hline Temizleme 2 atık & 4.29 & 15.47 \\
\hline Temizleme 3 atık & 6.98 & 19.76 \\
\hline Nihai konsantre & 15.07 & 14.98 \\
\hline \multirow[t]{2}{*}{ Besleme } & 0.23 & 100.00 \\
\hline & $\mathrm{Cu} \%$ & Cu Verim \% \\
\hline Flotasyon beslemesi & 0.02 & 81.59 \\
\hline Yaş manyetik ayırma atığı flotasyon şlamı & 0.22 & 16.47 \\
\hline Yaş manyetik ayırma atığı kaba şlamı & 0.21 & 1.95 \\
\hline Yaş manyetik ayırma atık & 0.23 & 100.00 \\
\hline
\end{tabular}

Çizelge 7. Cu flotasyonu çalışmalarında elde edilen en iyi deneysel sonuçlar. Table 7. Overall best results of Cu flotation experimental. 


\begin{tabular}{|l|c|c|c|c|}
\cline { 2 - 4 } \multicolumn{1}{c|}{} & $\mathrm{Na}_{2} \mathrm{~S}$ & $\mathrm{Na}-$ silikat & $\mathrm{Na}_{2} \mathrm{~S}_{2} \mathrm{O}_{5}$ & Aero3477+KAX \\
\hline Öğ̈̈tme & $250 \mathrm{~g} / \mathrm{t}$ & $1 \mathrm{~kg} / \mathrm{t}$ & - & - \\
\hline Koşullandırma & - & - & $300 \mathrm{~g} / \mathrm{t}$ & - \\
\hline Kaba flotasyon & - & - & - & $20 \mathrm{~g} / \mathrm{t}$ \\
\hline Süpürme flotasyonu & - & - & - & - \\
\hline Temizleme 1 & - & + & + & - \\
\hline Temizleme 2 & - & - & - & + \\
\hline Temizleme 3 & - & - & - & \\
\hline
\end{tabular}

Çizelge 8. Cu flotasyonu çalışmalarında elde edilen en iyi akım şemasına ilişkin flotasyon koşulları.

Table 8. Flotation conditions of the best $\mathrm{Cu}$ flotation flowsheet obtained.

Şekil 15'de görüldüğü gibi \%0.23 Cu tenörlü beslemeden üç aşama temizleme flotasyonu sonrasında yaklaşık \%19 Cu tenörlü bakır konsantresi \%52 verimle elde edilebilmektedir. Süpürme flotasyonu konsantresi ve Temizleme 1 atık akışları kaba flotasyon kondisyonerine geri çevrilmektedir. Temizleme 2 ve Temizleme 3 aşamalarının atıkları bir önceki aşamaya geri çevrilmektedir. Temizleme flotasyonu aşamalarına daha fazla malzemenin alınabilmesi için iki deneyin kaba flotasyon konsantreleri birleştirilmiştir. Cevherde bulunan kilin flotasyona olumsuz etkisini gidermek amacıyla öğütme aşamasında değirmene $1 \mathrm{~kg} / \mathrm{t}$ Na-Silikat eklenmiştir. Öğütme işlemi doğal pH'da ( $\mathrm{pH}=8)$, kaba flotasyon ise $\mathrm{pH}=11$ 'de gerçekleştirilmiştir. Toplayıcı olarak Aero3477+KAX karışımı kullanılmıştır. Kaba flotasyon konsantresi üç aşama temizleme flotasyonuna tabi tutulmuştur.

\section{CEVHERE ÖZGÜ AKIM ŞEMASININ GELIŞTiRILIMESi}

Son olarak manyetik ayırma ve flotasyon testleri verilerine dayanarak, cevhere uygun zenginleştirme akım şeması geliştirme çalışmaları gerçekleştirilmiştir. Tesis tasarımında, laboratuvar çalışmaları doğrultusunda öncelikle kırılmış ve öğütülmüş tuvenan cevher, azalan manyetik alan şiddetlerinde beş kademe düşük alan şiddetli yaş manyetik ayırmaya tabi tutulmuştur. İlk kademe manyetik ayırıcı atığı bakır flotasyonuna gönderilirken diğer ayırıcı atıkları bir önceki kademedeki manyetik ayırıcıya beslenmektedir. Beşinci kademe manyetik ayırıcı ürünü ise toplu sülfür flotasyonuna gönderilmektedir. Simülasyon kullanılarak tasarlanan akım şeması ve akışlara dair veriler Şekil 16 ve Şekil 17'de verilmektedir.

Akım şemasında toplu sülfür flotasyonu yüzen ürünü yine bakır flotasyon devresine gönderilirken, batan ürünün şlamı bir kabaran yataklı ayırıcıda atıldıktan sonra nihai 


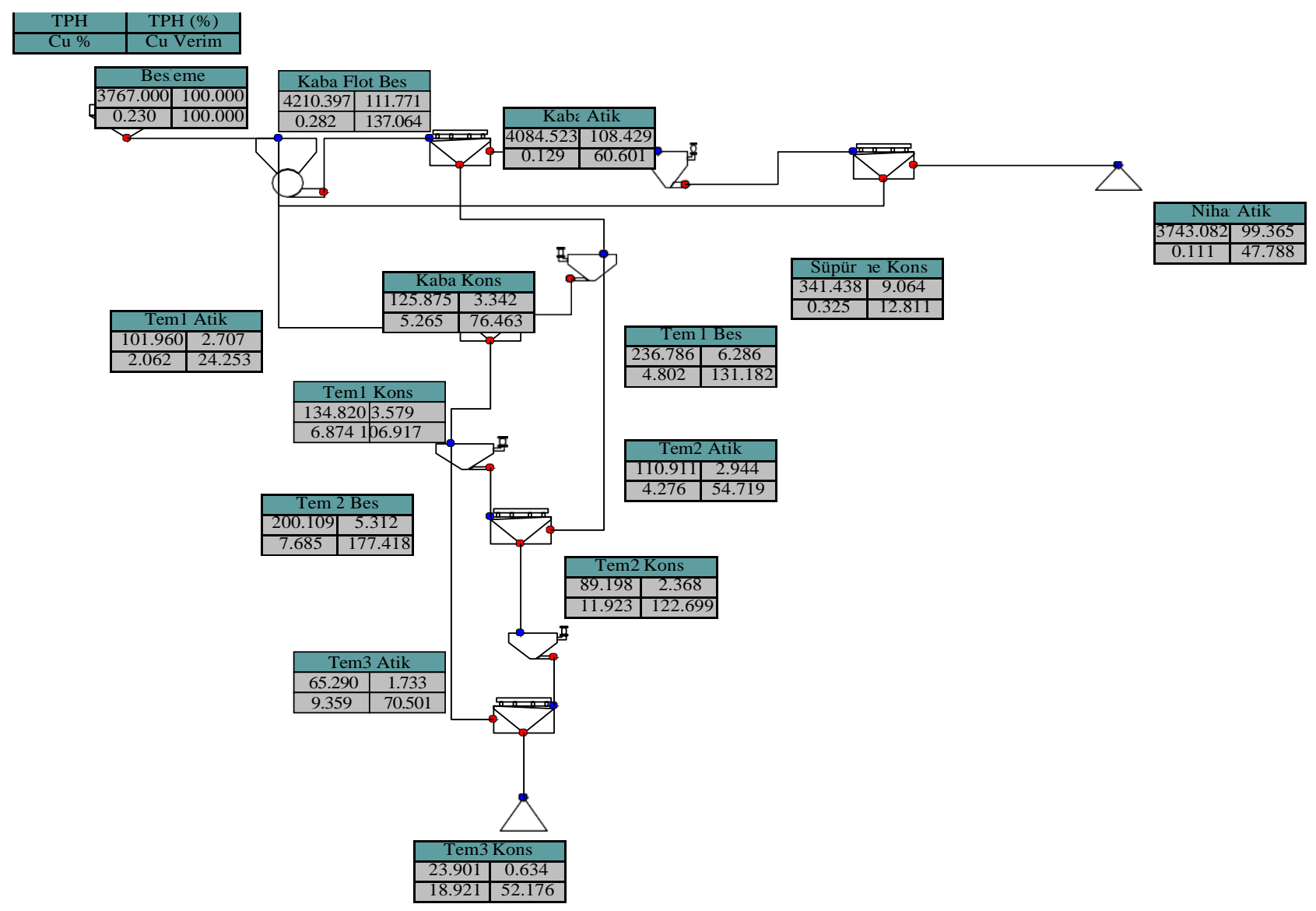

Şekil 15. Bakır flotasyon devresi simülasyon sonuçları.

Figure 15. Simulation results of copper flotation circuit.

manyetit konsantresi olarak alınmaktadır. Bakır flotasyonuna gelen cevher, kaba flotasyon sonrası üç kademe temizleme flotasyonuna tabi tutulmaktadır. Temizleme kademelerinde her bir kademe atığı bir önceki kademeye gönderilirken 3. Kademe temizleme ürünü nihai bakır konsantresi olarak alınmaktadır. Bakır kaba flotasyon atığı ve basit bir alttan akışı şlam atma sistemi (kabaran yataklı ayıııı) ile atılan şlam ise nihai atığı oluşturmaktadır.

Açık devre laboratuvar testlerinde ilk kademe manyetik ayırmada manyetit kazanımı \%99 gibi oldukça yüksek düzeydedir. Fakat temizlemenin son aşamasında bu oran \%96 değerine kadar düşmektedir. Bu durumda temizleme atıklarının önceki aşamalara geri döndürülmesi ile nihai üründeki toplam demir kazanımın artacağı anlaşılmaktadır. Bu nedenle manyetik ayırma devresi için her bir aşamanın kütle bölme oranları kullanılarak apalı devre çalışmanın etkisi simülasyon yoluyla belirlenmiştir. 


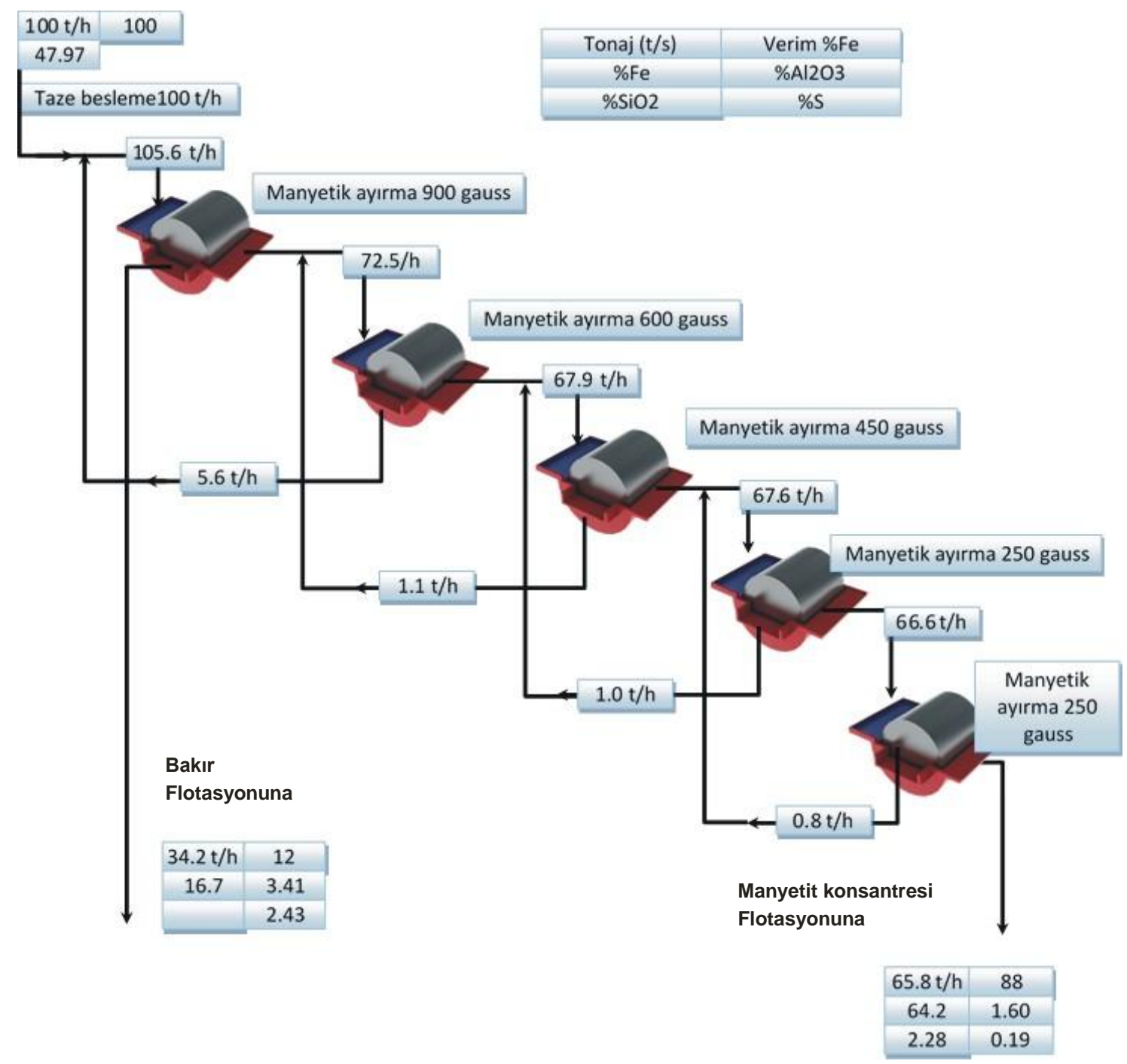

Şekil 16. Manyetik ayırma devresi akım şeması ve $100 \mathrm{t} / \mathrm{s}$ tesis kapasitesi için akışlara ait veriler.

Figure 16. Flowsheet for the magnetic separation circuit and flow regimes calculated for a $100 \mathrm{t} / \mathrm{h}$ plant.

Benzer şekilde laboratuvar flotasyon verileri yardımıyla da flotasyon devresi için kapalı devre simülasyonu yapıımıştır.

Buna göre ilgili cevherin tasarlanan akım şeması ile 100 t/s kapasitede, \%87-88 demir verimi ile saatte 63.9 ton \%65.5-66.5 Fe tenörlü manyetit konsantresi ve yaklaşık \%47 verimle saatte 0.22 ton \%18-19 Cu tenörlü bakır konsantresi alınacağı ve saatte 35.84 ton atık ortaya çıkacağı belirlenmiştir. 


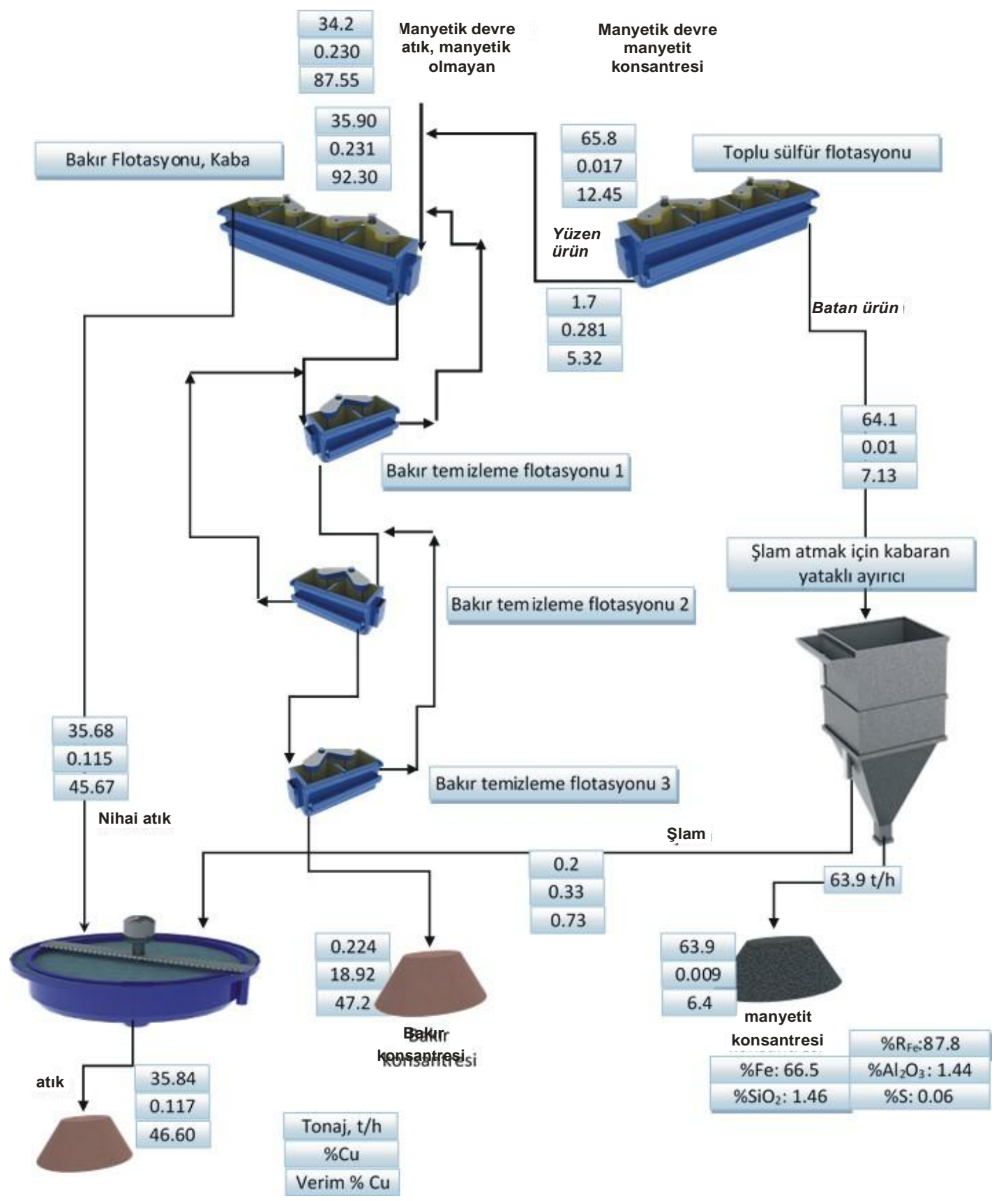

Şekil 17. Flotasyon devresi akım şeması ve $100 \mathrm{t} / \mathrm{s}$ tesis kapasitesi için akışlara ait veriler.

Figure 17. Flowsheet for the flotation circuit and flow regimes calculated for a $100 \mathrm{t} / \mathrm{h}$ plant.

\section{SONUÇLAR}

Bu çalışmada, Erzincan bölgesinde bulunan demir cevherinin zenginleştirilebilirliğine yönelik detaylı karakterizasyon ve deneysel çalışmalar gerçekleştirilmiştir. Manyetik 
ayırma testlerinde gerekli inceliğe öğütülmüş cevher sırasıyla 900, 600, 450 ve 2 defa da 250 gauss alan şiddetlerine sahip manyetik ayırıcıdan geçirilerek beş kademe temizleme işlemine tabi tutularak bir manyetik ürün üretilmiştir. Manyetik ayırma atığı ise bakır flotasyonuna tabi tutularak satılabilir bakır konsantresi elde edilmiştir.

Elde edilen sonuçlar cevhere özgü zenginleştirilebilirlik stratejileri geliştirmede kullanılmıştır. Bu sonuçlar doğrultusunda cevher inceldikçe demir içeriği yüksek ve impürite içerikleri açısından görece düşük içerikli ürünler üretilebileceğini göstermektedir. Elde edilen ürünlerin demir içerikleri yeterince yüksek olmakla birlikte, sonuçlar yaş manyetik ayırmanın da tek başına yeterince temiz ürün üretmekte yeterli olmadığını göstermiş, sonrasında manyetik ürünün toplu sülfür flotasyonuna tabi tutulması ile impüritelerin daha da azaltılabileceği belirlenmiştir. Ayrıca manyetik ayırma sonrasında flotasyonla sülfür içeriği düşürülen nihai konsantreden kaba bir çökelme tankı ile şlam atılması durumunda silis, alümina ve magnezyum içerikleri daha düşük ürünler elde edilebileceği sonucuna varılmıştır. Cevher bünyesinde kil varlığı, konsantrelerdeki kükürt içeriği, manyetitin yer yer morfolojik bozunmaya uğramış olması, ince boylarda çok kademeli ve kontrollü manyetik ayırma testlerinin gerekliliği gibi cevhere özgü zorluklara rağmen, geleneksel yöntemlerle satılabilir konsantreler mümkün olan en yüksek verimlerle elde edilebilmiştir.

\section{KATKI BELIRTME}

BíLFER MADENCILIK VE TURIZM A.Ş.'ye veri kullanımı ve yayılması konusundaki desteklerinden dolayı teşekkür ederiz.

\section{KAYNAKLAR}

Clout J.M.F., Manuel J.R., 2015. Mineralogical, chemical and physical characteristics of iron ore. In: Lu, Liming (Ed.), Iron Ore: Mineralogy, Processing and Environmental Sustainability. Elsevier, (Chapter 2), sayfa 45-84.

Ezhov A.M., Shvaljov Y.B., 2015. Dry magnetic separation of iron ore of the Bakchar deposit. Procedia Chem. 15, sayfa 160-166.

Gupta A., Yan D., 2016a. Mineral Processing Design and Operations (Second Edition), Chapter 16 - Gravity Separation, Elsevier, sayfa 563-628, ISBN 9780444635891.

Gupta A., Yan D., 2016b. Mineral Processing Design and Operations (Second Edition), Chapter 17 - Magnetic and Electrostatic Separation, Elsevier, sayfa 629-687, ISBN 9780444635891. 
Gupta A., Yan D., 2016c. Mineral Processing Design and Operations (Second Edition), Chapter 18 - Flotation, Elsevier, sayfa 689-741, ISBN 9780444635891.

Haldar S.K., Tišljar J., 2014. Chapter 2 - Basic Mineralogy, Editor(ler): S.K. Haldar, Josip Tišljar, Introduction to Mineralogy and Petrology, Elsevier, sayfa 39-79, ISBN 9780124081338.

Holmes R.J., Lu L., 2015. 1 - Introduction: overview of the global iron ore industry, Editor(ler): Liming Lu, Iron Ore, Woodhead Publishing, sayfa 1-42, ISBN 9781782421566.

Jankovic A., 2015. 8 - Developments in iron ore comminution and classification technologies, Editor(s): Liming Lu, Iron Ore, Woodhead Publishing, sayfa 251282, ISBN 9781782421566.

Lovel R.R., Sparrow G.J., Fisher-White M.J., 2015. 12 - Developments in chemical separation of iron ore, Editor(ler): Liming Lu, Iron Ore, Woodhead Publishing, sayfa 357-372, ISBN 9781782421566.

Maré E., Beven B., Crisafio C., 2015. 10 - Developments in nonmagnetic physical separation technologies for hematitic/goethitic iron ore. Iron Ore, Mineralogy, Processing and Environmental Sustainability, sayfa 309-338.

Quast K., 2018. A review on the characterisation and processing of oolitic iron ores, Minerals Engineering 126, sayfa 89-100.

Rousseau R.W., 1987. Handbook of Separation Process Technology, John Wiley \& Sons, 1010, ISBN 9780750644501.

Song S., Lu S., Lopez-Valdivieso A., 2002. Magnetic separation of hematite and limonite fines as hydrophobic flocs from iron ores. Minerals Engineering 15, sayfa $415-422$.

Tim Napier-Munn, 2005. Wills' Mineral Processing Technology (Seventh Edition), Editor(ler): Barry A. Wills, Tim Napier-Munn, 7th Edition, ButterworthHeinemann, sayfa 225-245.

Xiong D., Lu L., Holmes R.J., 2015. 9-Developments in the physical separation of iron ore: magnetic separation. In: Lu, L. (Ed.), Iron Ore - Mineralogy, Processing and Environmental Sustainability. Elsevier, sayfa 283-307.

Xionga W., Dengb J., Chenb B., Dengb S., Weia D., 2018. Flotation-magnetic separation for the beneficiation of rare earth ores. Minerals Engineering 119, sayfa $49-56$.

Wanga S., Guoa K., Qia S., Lub L., 2018. Effect of frictional grinding on ore characteristics and selectivity of magnetic separation. Minerals Engineering 122, sayfa $251-257$. 